\title{
Zero to moderate methane emissions in a densely rooted, pristine Patagonian bog - biogeochemical controls as revealed from isotopic evidence
}

\author{
Wiebke Münchberger $^{1,2}$, Klaus-Holger Knorr ${ }^{1}$, Christian Blodau ${ }^{1, \dagger}$, Verónica A. Pancotto ${ }^{3,4}$, and Till Kleinebecker ${ }^{2,5}$ \\ ${ }^{1}$ Ecohydrology and Biogeochemistry Research Group, Institute of Landscape Ecology, University of Münster, \\ Heisenbergstraße 2, 48149 Münster, Germany \\ ${ }^{2}$ Biodiversity and Ecosystem Research Group, Institute of Landscape Ecology, University of Münster, \\ Heisenbergstraße 2, 48149 Münster, Germany \\ ${ }^{3}$ Centro Austral de Investigaciones Científicas (CADIC-CONICET), B. Houssay 200, \\ 9410 Ushuaia, Tierra del Fuego, Argentina \\ ${ }^{4}$ Instituto de Ciencias Polares y Ambiente (ICPA-UNTDF), Fuegia Basket, 9410 Ushuaia, \\ Tierra del Fuego, Argentina \\ ${ }^{5}$ Institute of Landscape Ecology and Resources Management, Justus Liebig University Giessen, \\ Heinrich-Buff-Ring 26, 35392 Gießen, Germany \\ $\dagger$ deceased, July 2016
}

Correspondence: Wiebke Münchberger (wiebke.muenchberger@uni-muenster.de) and Klaus-Holger Knorr (kh.knorr@uni-muenster.de)

Received: 22 June 2018 - Discussion started: 28 August 2018

Revised: 21 December 2018 - Accepted: 20 January 2019 - Published: 31 January 2019

\begin{abstract}
Peatlands are significant global methane $\left(\mathrm{CH}_{4}\right)$ sources, but processes governing $\mathrm{CH}_{4}$ dynamics have been predominantly studied in the Northern Hemisphere. Southern hemispheric and tropical bogs can be dominated by cushionforming vascular plants (e.g. Astelia pumila, Donatia fascicularis). These cushion bogs are found in many (mostly southern) parts of the world but could also serve as extreme examples for densely rooted northern hemispheric bogs dominated by rushes and sedges. We report highly variable summer $\mathrm{CH}_{4}$ emissions from different microforms in a Patagonian cushion bog as determined by chamber measurements. Driving biogeochemical processes were identified from pore water profiles and carbon isotopic signatures. Intensive root activity throughout a rhizosphere stretching over $2 \mathrm{~m}$ in depth accompanied by molecular oxygen release created aerobic microsites in water-saturated peat, leading to a thorough $\mathrm{CH}_{4}$ oxidation $\left(<0.003 \mathrm{mmol} \mathrm{L}^{-1}\right.$ pore water $\mathrm{CH}_{4}$, enriched in $\delta^{13} \mathrm{C}-\mathrm{CH}_{4}$ by up to $10 \%$ o) and negligible emissions $(0.09 \pm$ $0.16 \mathrm{mmol} \mathrm{CH}_{4} \mathrm{~m}^{-2} \mathrm{~d}^{-1}$ ) from Astelia lawns. In sparsely or even non-rooted peat below adjacent pools pore water profile patterns similar to those obtained under Astelia
\end{abstract}

lawns, which emitted very small amounts of $\mathrm{CH}_{4}(0.23 \pm$ $0.25 \mathrm{mmol} \mathrm{m}^{-2} \mathrm{~d}^{-1}$ ), were found. Below the A. pumila rhizosphere pore water concentrations increased sharply to $0.40 \pm 0.25 \mathrm{mmol} \mathrm{CH}_{4} \mathrm{~L}^{-1}$ and $\mathrm{CH}_{4}$ was predominantly produced by hydrogenotrophic methanogenesis. A few Sphagnum lawns and - surprisingly - one lawn dominated by cushion-forming D. fascicularis were found to be local $\mathrm{CH}_{4}$ emission hotspots with up to $1.52 \pm 1.10 \mathrm{mmol} \mathrm{CH}_{4} \mathrm{~m}^{-2} \mathrm{~d}^{-1}$ presumably as root density and molecular oxygen release dropped below a certain threshold. The spatial distribution of root characteristics supposedly causing such a pronounced $\mathrm{CH}_{4}$ emission pattern was evaluated on a conceptual level aiming to exemplify scenarios in densely rooted bogs. We conclude that presence of cushion vegetation as a proxy for negligible $\mathrm{CH}_{4}$ emissions from cushion bogs needs to be interpreted with caution. Nevertheless, overall ecosystem $\mathrm{CH}_{4}$ emissions at our study site were probably minute compared to bog ecosystems worldwide and widely decoupled from environmental controls due to intensive root activity of A. pumila, for example. 


\section{Introduction}

Peatland ecosystems are significant natural methane $\left(\mathrm{CH}_{4}\right)$ sources on the global scale responsible for about $10 \%$ of global annual CH4 emissions (Aselmann and Crutzen, 1989; Mikaloff Fletcher et al., 2004). $\mathrm{CH}_{4}$ has a 28 -fold higher global warming potential over a 100 -year time horizon compared to carbon dioxide $\left(\mathrm{CO}_{2}\right)$ (IPCC, 2014) and, thus, processes governing $\mathrm{CH}_{4}$ dynamics in peatlands receive much attention to estimate global greenhouse gas emissions.

The slowdown of decomposition and accumulation of $\mathrm{C}$ in rainwater-fed peatlands (bogs) results from a high water table, anoxic conditions, recalcitrant peat-forming litter, low temperatures, inactivation of oxidative enzymes and an accumulation of decomposition end products (Beer and Blodau, 2007; Limpens et al., 2008; Bonaiuti et al., 2017). Once methanogenic conditions are established, $\mathrm{CH}_{4}$ production is mainly controlled by a substrate supply of labile organic matter (Hornibrook et al., 1997; Whalen, 2005). Then, slow diffusive transport along the concentration gradient from deep anoxic peat layers to the atmosphere leads to $\mathrm{CH}_{4}$ release. In upper, unsaturated and oxic peat zones that typically extend only about a few decimetres (Whalen, 2005; Limpens et al., 2008), $\mathrm{CH}_{4}$ might get consumed by methanotrophic microbes (Chasar et al., 2000; Whalen, 2005; Berger et al., 2018). Consequently, water table position and fluctuations strongly control the amount of emitted $\mathrm{CH}_{4}$ (Blodau and Moore, 2003; Whalen, 2005). While $\mathrm{CH}_{4}$ oxidation suppresses $\mathrm{CH}_{4}$ emissions in diffusion-dominated systems, ebullition by fast release of gas bubbles or plant-mediated transport by aerenchymatic roots can substantially increase $\mathrm{CH}_{4}$ emissions (Fechner-Levy and Hemond, 1996; Joabsson et al., 1999, and references therein; Chasar et al., 2000; Colmer, 2003; Whalen, 2005; Knoblauch et al., 2015; Burger et al., 2016; Berger et al., 2018). With a high share of ebullitive fluxes, vegetated or open water pools in peatlands are considered to be strong $\mathrm{CH}_{4}$ emitters (Hamilton et al., 1994; Blodau 2002; Burger et al., 2016) that have, however, received less attention than the vegetated surfaces (Pelletier et al., 2014). Pools can even turn the peatlands' $\mathrm{C}$ balance into a source (Pelletier et al., 2014), but examples of low-emission pools have also been reported (Knoblauch et al., 2015).

Carbon isotopic signatures $\left(\delta^{13} \mathrm{C}\right)$ are a valuable tool for identifying mechanisms and pathways of $\mathrm{CH}_{4}$ dynamics. Carbon isotopic signatures in pore water of northern hemispheric bogs (hereafter termed northern bogs) vary typically between $-80 \%$ and $-50 \%$ and between $-25 \%$ and $+10 \%$ for $\mathrm{CH}_{4}$ and $\mathrm{CO}_{2}$, respectively (e.g. Whiticar et al., 1986; Hornibrook et al., 1997, 2000; Chasar et al., 2000; Beer et al., 2008; Steinmann et al., 2008; Corbett et al., 2013). Depending on the available substrate for methanogenesis, it was mostly observed that either the acetoclastic or hydrogenotrophic pathway predominates, resulting in distinctive carbon isotope signatures of $\mathrm{CH}_{4}$ (acetate fermentation $\delta^{13} \mathrm{C}_{-} \mathrm{CH}_{4} \sim-65 \%$ to $-50 \%$ o, $\mathrm{CO}_{2}$ reduction $\delta^{13} \mathrm{C}$ -
$\mathrm{CH}_{4} \sim-110$ to $-60 \%$ ) (Whiticar et al., 1986). Methane is prevailingly produced by acetoclastic methanogenesis when fresh, labile organic matter is available, whereas the production pathway shifts towards hydrogenotrophic methanogenesis when organic matter becomes increasingly recalcitrant (Hornibrook et al., 1997; Popp et al., 1999; Chasar et al., 2000; Conrad, 2005). A predominance of the latter pathway is indicated by strong fractionation between ${ }^{12} \mathrm{C} /{ }^{13} \mathrm{C}$, resulting in relatively depleted $\delta^{13} \mathrm{C}-\mathrm{CH}_{4}$ corresponding to a fractionation factor $\alpha_{\mathrm{c}}$ of between 1.055 and 1.090 (Whiticar et al., 1986) and a $\delta^{13} \mathrm{C}_{-} \mathrm{CH}_{4}$ isotopic signature following that of $\delta^{13} \mathrm{C}-\mathrm{CO}_{2}$ (Hornibrook et al., 2000). Subsequent methanotrophy alters the isotopic signature of $\mathrm{CH}_{4}$ by discriminating against ${ }^{13} \mathrm{C}$ and the residual $\mathrm{CH}_{4}$ remains enriched while produced $\mathrm{CO}_{2}$ becomes depleted in ${ }^{13} \mathrm{C}$ (Chasar et al., 2000; Popp et al., 1999). As both, acetoclastic methanogenesis and methanotrophy, result in a $\delta^{13} \mathrm{C}_{-} \mathrm{CH}_{4}$ signature enriched in ${ }^{13} \mathrm{C}$ and a small apparent fractionation factor (Whiticar et al., 1986; Conrad, 2005), the acetoclastic pathway cannot be clearly separated from methanotrophic conditions based on carbon isotopes only (Conrad, 2005).

The majority of studies elucidating $\mathrm{CH}_{4}$ dynamics in peatlands have been conducted on the Northern Hemisphere (e.g. Blodau, 2002; Limpens et al., 2008; Yu, 2012, and references in these), whereas only little research deals with $\mathrm{CH}_{4}$ dynamics in bogs on the Southern Hemisphere (hereafter termed southern bogs) (Broder et al., 2015). Contrary to northern bogs, southern bogs are not only vegetated by Sphagnum mosses, dwarf shrubs or a few graminoids such as the rushlike species Tetroncium magellanicum, but also by vascular plants (Kleinebecker et al., 2007) that can densely root upper peat layers (Fritz et al., 2011; Knorr et al., 2015). Another feature that can be found in both systems is pools with sparse or no vegetation (Fritz et al., 2011; González Garraza et al., 2018). The vascular plants, for instance of the genus Astelia (Asteliaceae), Donatia (Stylidiaceae) or Oreobolus (Cyperaceae), independently developed a cushion life form to protect from harsh climate in cold environments (Gibson and Kirkpatrick, 1985; Boucher et al., 2016). Bogs dominated by cushion-forming vascular plants (hereafter termed cushion bogs) can be found in many (mostly southern) parts of the world, for instance all along the high Andes (Coombes and Ramsay, 2001; Benavides et al., 2013; Fonkén, 2014) down to southernmost Patagonia (Ruthsatz and Villagran, 1991; Heusser, 1995; Kleinebecker et al., 2007; Grootjans et al., 2014), in the highlands of eastern Africa (Dullo et al., 2017) as well as in New Guinea (Hope, 2014), New Zealand, and Tasmania (Gibson and Kirkpatrick, 1985; Ruthsatz and Villagran, 1991) and some sub-Antarctic islands (Ruthsatz and Villagran, 1991). These cushion bogs could also be regarded as extreme examples for densely rooted northern bogs that are dominated by rushes and sedges.

To our knowledge, only two studies reported $\mathrm{CH}_{4}$ emissions from southern vascular-plant-dominated bogs with quite inconsistent results. Over a New Zealand bog domi- 
nated by the evergreen "wire rush" Empodisma robustum, $\mathrm{CH}_{4}$ emissions exceeded those commonly reported from northern bogs (Goodrich et al., 2015), while emissions from a Patagonian cushion bog dominated by Astelia pumila were negligible (Fritz et al., 2011). Both, high and negligible $\mathrm{CH}_{4}$ emissions, were mainly explained by the extensive aerenchymous roots of the prevailing plant species: the aerenchyma might function as a conduit for $\mathrm{CH}_{4}$ from deep peat layers to the atmosphere in the first case, whereas in the second case pronounced $\mathrm{O}_{2}$ supply by roots might have resulted in a thorough oxidation of pore water $\mathrm{CH}_{4}$ and enhanced organic matter decomposition. However, Fritz et al. (2011) were the first to investigate $\mathrm{CH}_{4}$ dynamics below Astelia lawns and determined emissions only sporadically without considering all predominant microforms and plant communities. Thus, general conclusions about $\mathrm{CH}_{4}$ emissions from this type of ecosystem are so far restricted. Furthermore, more knowledge on biogeochemical processes throughout the peat column of Astelia lawns as a model plant for cushion-forming aerenchymous plants and in other microforms is needed to extend our limited understanding of these first insights into $\mathrm{CH}_{4}$ dynamics in cushion bogs. Despite the variety of bogs dominated by densely rooted aerenchymous plants in the Northern Hemisphere and Southern Hemisphere, there is some evidence from the latest research that very low $\mathrm{CH}_{4}$ pore water concentrations could be a more common phenomenon in those ecosystems (Knorr et al., 2015; Dullo et al., 2017; Agethen et al., 2018). In general, promotion or suppression of $\mathrm{CH}_{4}$ production should be determined by the ratio of root density and activity associated with $\mathrm{O}_{2}$ release versus presence of labile root organic matter or exudates accompanied by $\mathrm{O}_{2}$ consumption (Blodau, 2002; Agethen et al., 2018).

Here, we quantified austral summer $\mathrm{CH}_{4}$ emissions from dominant microforms in a Patagonian cushion bog and examined possible environmental and biogeochemical controls. We hypothesized that (i) emissions from cushion plant vegetation dominated by Astelia pumila or Donatia fascicularis are negligible while pools and Sphagnum lawns emit $\mathrm{CH}_{4}$ in considerable amounts; (ii) pore water $\mathrm{CH}_{4}$ and dissolved inorganic carbon (DIC) concentration profiles and their carbon isotopic signatures below densely rooted Astelia lawns reflect a distinct $\mathrm{CH}_{4}$ oxidation effect contrary to sparsely or even non-rooted peat below pools; and (iii) in addition to by methanotrophy, isotopic composition of pore water $\mathrm{CH}_{4}$ could also be affected by a predominance of acetoclastic methanogenesis throughout the rhizosphere of Astelia lawns shifting towards $\mathrm{CO}_{2}$ reduction with peat depth and in sparsely or even non-rooted peat below pools. Biogeochemical controls of $\mathrm{CH}_{4}$ emissions from Sphagnum lawns were not the subject of this study, as they have been intensively studied in northern bogs (e.g. Hornibrook et al., 1997; Beer and Blodau, 2007; Steinmann et al., 2008; Corbett et al., 2013) and even southern bogs with mixed vegetation in the absence of notable cushion plant coverage (Broder et al., 2015).

\section{Material and methods}

\subsection{Description of the study site}

The study was conducted at a cushion bog on the Península Mitre in southernmost Patagonia, Tierra del Fuego (Moat, $54^{\circ} 58^{\prime}$ S, $66^{\circ} 44^{\prime}$ W; Fig. 1). Peatlands of the Península Mitre provide the today rare opportunity to study carbon dynamics under pristine conditions as they can be considered largely undisturbed by human activities such as drainage, agriculture or elevated atmospheric nitrogen deposition (Kleinebecker et al., 2008; Fritz et al., 2011; Grootjans et al., 2014; Paredes et al., 2014). About $45 \%$ of this area is covered by peatlands (Iturraspe, 2012) while little is known about these ecosystems because of their poor accessibility (Iturraspe, 2012). The study site at Moat belongs to a complex system of sloping mires, blanket bogs, fens and - in coastal areas - cushion bogs (Iturraspe, 2012; Borromei et al., 2014). The studied cushion bog is located in exposed proximity to the Beagle Channel with harsh winds (Grootjans et al., 2014), resulting in an oceanic climate with average daily temperatures of $6^{\circ} \mathrm{C}$ and annual precipitation of $500 \mathrm{~mm}$ (Fritz, 2012).

Large areas of the cushion bogs in Moat are characterized by a comparatively flat microrelief and covered by the cushion-forming plants Astelia pumila and Donatia fascicularis. The vegetation of the studied bog is composed of a mosaic of different plant communities characterized by specific plant species with lawns of $A$. pumila being the prevailing microform. Sphagnum magellanicum or D. fascicularis grow in small lawns (patches of a few square metres) at pool margins where $S$. magellanicum supposedly benefits from protection against desiccation. Tetroncium magellanicum, a rush-like herb that does not form cushions but presumably establishes aerenchymous roots as it tolerates inundation (von Mehring, 2013), is associated predominantly with Sphagnum lawns but also with Astelia and Donatia lawns, or it sporadically inhabits pools. These sparsely vegetated pools of different size $\left(<0.5 \mathrm{~m}^{2}-\sim 10 \mathrm{~m}^{2}\right)$ and $\sim 0.5 \mathrm{~m}$ in depth are embedded in Astelia lawns. Pool sediments are inhabited by cyanobacteria (Arsenault et al., 2018; González Garraza et al., 2018) and submerged Sphagnum mosses such as Sphagnum cuspidatum (Kleinebecker et al., 2007; Kip et al., 2012). Peat formation started $\sim 11000$ years ago (Borromei et al., 2014), and previously the bog was dominated by $S$. magellanicum while A. pumila invaded the area around 2600 years before present as determined by pollen analyses (Heusser, 1995). The peat below Astelia lawns is densely rooted with an average of $2.15 \mathrm{~g} \mathrm{DW} \mathrm{L}$ of peat ${ }^{-1}$ down to $1.7 \mathrm{~m}$ (Fritz et al., 2011). Mean root lifetimes of A. pumila have been estimated to be $\sim 3-4$ years, indicating a high root turnover (Knorr et al., 2015). 


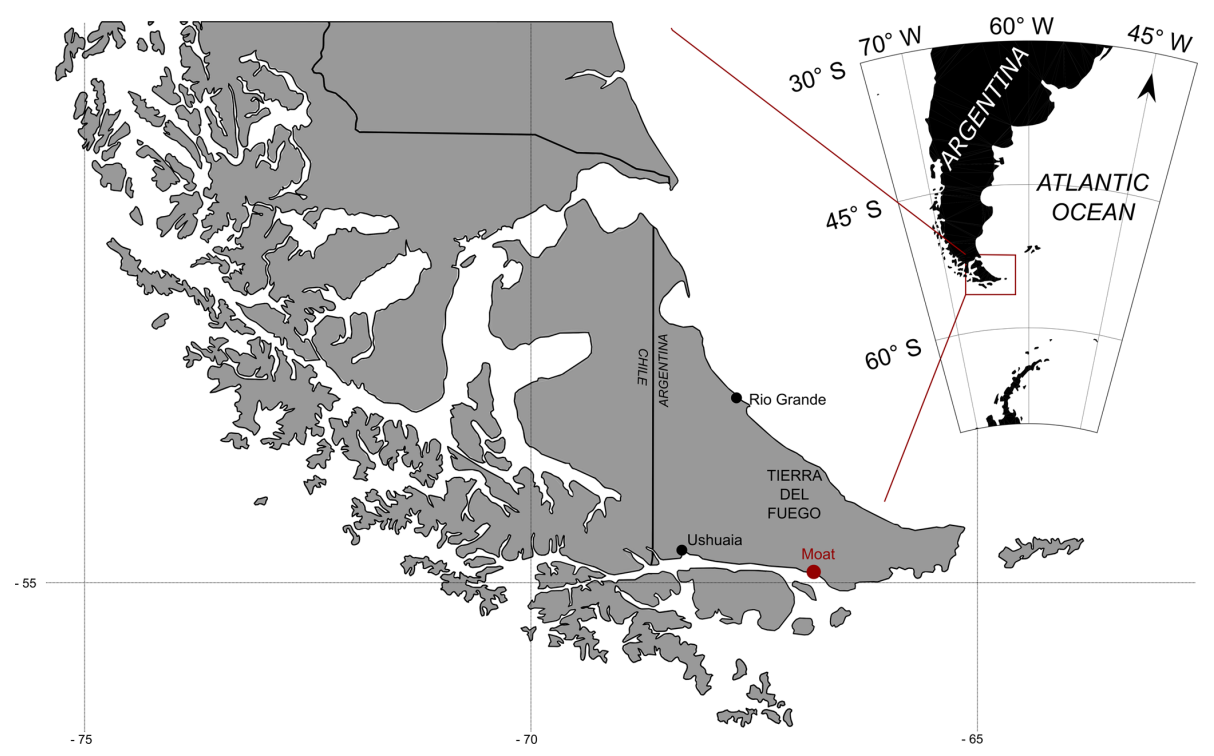

Figure 1. Location of the study area in southernmost Patagonia. The investigated cushion bog in Moat is located $130 \mathrm{~km}$ east of Ushuaia (Argentina). The map was created at http://www.simplemappr.net (last access: 11 December 2017) and in MATLAB (MATLAB Mapping Toolbox Release R2017a).

\subsection{Sampling and analysis of solid peat and root biomass}

Peat coring in Astelia and Sphagnum lawns (data not shown) was carried out using a Russian peat corer (Eijkelkamp Agrisearch Equipment, Giesbeek, the Netherlands) down to a maximum depth of $7.5 \mathrm{~m}$ in Astelia lawns. Roots of A. pumila in Astelia lawn cores were sorted out and treated separately. The density of $D$. fascicularis root biomass was determined by cutting three $0.1 \times 0.1 \mathrm{~m}$ sods down to a depth of $0.4 \mathrm{~m}$. Peat and root biomass samples were oven dried at $70^{\circ} \mathrm{C}$ until a constant weight to calculate peat bulk density and porosity as well as $D$. fascicularis root density. Total $\mathrm{C}$ and $\mathrm{N}$ contents together with abundance of ${ }^{15} \mathrm{~N}$ and ${ }^{13} \mathrm{C}$ in the solid peat were determined using an elemental analyser (EA 3000, EuroVector, Redavalle, Italy) connected to an isotope ratio mass spectrometer (IRMS, Nu Instruments, Wrexham, UK).

\subsection{Environmental variables}

Environmental variables were determined during two measurement campaigns in 2015 and 2016 at half-hourly intervals. Photosynthetic active radiation (PAR, HOBO S-LIAM003, Onset, USA, up to $2500 \mu \mathrm{mol} \mathrm{m}^{-2} \mathrm{~s}^{-1}$ ) and air temperature (HOBO S-TMB-M0x, Onset, USA) were recorded by a weather station (HOBO U30 NRC, Onset, USA) in both years during austral summer months. Water table fluctuations at two replicate sites in Astelia lawns (Levelogger Edge 3001 and Barologger Edge, Solinst, Canada; both installed in perforated PVC tubes) and soil temperature at four depths of $0.05,0.1,0.3$ and $0.5 \mathrm{~m}$ (HOBO TMCX-HD and HOBO U12-008, Onset, USA) were measured continuously.

\subsection{Chamber measurements and analyses of soil-atmosphere $\mathrm{CH}_{4}$ fluxes}

\subsubsection{Field measurements}

The closed chamber technique was used to determine $\mathrm{CH}_{4}$ fluxes during two measurement campaigns in austral summer from December 2014 to March 2015 and in February and March 2016. A total of 1 week prior to measurements, PVC collars with a height of $0.2 \mathrm{~m}$ were permanently installed $\sim 0.15 \mathrm{~m}$ into the peat of the dominant microforms characterized by a specific plant species and a particular plant community (Astelia lawns: $2015 \mathrm{~N}=3,2016 \mathrm{~N}=5$; Sphagnum lawns: $2015 \mathrm{~N}=3,2016 \mathrm{~N}=5$; Donatia lawns: 2016 $\mathrm{N}=3$ ). The exact installation depth and the microrelief of the surface within each collar were determined repeatedly to calculate the exact headspace volume for $\mathrm{CH}_{4}$ flux estimation. The collars were equally arranged around three wooden platforms constructed in January 2014 to minimize disturbance during measurements and distributed over the study site to account for spatial variability (see the Supplement). Different numbers of replicates between the two campaigns and the different microforms are the result of logistical constraints.

A cylindrical, transparent chamber with a basal area of $0.13 \mathrm{~m}^{2}$ and a height of $0.4 \mathrm{~m}$ was used for soil-atmosphere flux measurements. The chamber was equipped with a fan to ensure mixing of the headspace air, a PAR sensor (HOBO SLIA-M003, Onset, USA) and a temperature sensor (HOBO S-TMB-M0x, Onset, USA). A second temperature sensor recorded ambient temperature (HOBO S-TMB-M0x, Onset, USA) and all sensor data were logged in $1 \mathrm{~s}$ intervals to a data 
logger (HOBO U30 NRC, Onset, USA). This set-up allowed us to control air temperature inside the chamber within an approximately $3{ }^{\circ} \mathrm{C}$ deviation of the ambient air temperature. If necessary, ice packs were installed inside the chamber to avoid temperature increase. Due to strong wind conditions we decided against the installation of a vent tube. An opening in the top of the chamber avoided overpressure during chamber placement. This opening was closed immediately after the chamber was gently placed on a collar for at least 3 min to conduct measurements. Collars were equipped with a water-filled rim to ensure a gas-tight seal between chamber and collar during measurements. Pool fluxes were performed with a floating chamber of identical dimension and design on four pools located at each platform. The chamber wall extended approximately $0.04 \mathrm{~m}$ into the water during measurements.

All measurements were performed under a broad range of irradiance between 07:00 and 22:00 (local time) to determine diurnal variations in $\mathrm{CH}_{4}$ fluxes. At least once during each sampling period of 2 to 3 consecutive days, all selected microforms and pools were measured under dark conditions. Opaque, reflective material was used to cover the chamber for dark conditions. Measurements were taken every 2 weeks during the first campaign in $2015(\mathrm{~N}=405$ measurements) and on two occasions in 2016 ( $N=132$ measurements). A more regular measurement routine throughout the whole season was constrained by harsh weather conditions and the remoteness of our study site.

The chamber was connected by a $2 \mathrm{~mm}$ inner diameter polyethylene tubing to a gas analyser (Los Gatos ultraportable greenhouse gas analyser 915-001, Los Gatos Research) to record the increase in $\mathrm{CH}_{4}$ concentrations over time at a rate of $1 \mathrm{~Hz}$. Between measurements, atmospheric background concentrations were achieved inside the chamber. The gas analyser was equipped with an external pump providing a flow rate of $2 \mathrm{~L} \mathrm{~min}^{-1}$ and pumping the analysed gas back to the chamber, creating a closed system. Prior to each campaign, the instrument was recalibrated.

We estimated the cover of plant species within each collar to the nearest $5 \%$ and counted the number of T. magellanicum shoots to further characterize the different microforms (Table 1). In 2015, vegetation surveys were conducted at the beginning and at the end of the measurement campaign. Since no change in vegetation was observed, surveys were conducted only once during the campaign in 2016. For each collar, the position above the water table was determined once during each sampling period of consecutive days to account for different positions in the microrelief and to determine a specific water table position. Additionally, we determined the area of each individual microform patch in which a collar had been installed.

\subsection{2 $\mathrm{CH}_{4}$ flux calculation and statistical analyses}

Soil-atmosphere $\mathrm{CH}_{4}$ fluxes were calculated from the gas concentration increase over time within the chamber using the software package (MATLAB Release R2015a) routine described in Eckhardt and Kutzbach (2016) and Kutzbach et al. (2007). Gas concentration was modelled as either a linear or exponential function of time. Model performance was compared using Akaike's information criterion (AIC) as a measure of goodness of fit. This routine resulted in $90 \%$ of cases in a linear function of time $(\mathrm{N}=485)$ and in $10 \%$ of cases in an exponential function of time $(\mathrm{N}=52)$.

We visually inspected all concentration increases over time and none of the measurements showed a stepwise concentration increase indicative of ebullient events. Of the 3 min measurement time, 50-180 s (mostly around 90 s) was selected for the $\mathrm{CH}_{4}$ flux calculation to exclude unstable conditions due to chamber placement, particularly at the beginning of the measurement. Fluxes with a slope not significantly different from 0 (tested with an $F$ test, $p>0.05$ ) were set to zero ( $20 \%$ of cases, $\mathrm{N}=105)$.

Normal distributions of $\mathrm{CH}_{4}$ flux datasets were checked by a Kolmogorov-Smirnov test. Due to non-normality, the Kruskal-Wallis analysis of variance followed by multiple comparison $U$ tests adjusted by the Bonferroni method were applied to determine significant differences among $\mathrm{CH}_{4}$ fluxes of different microforms and collars. The relationships between $\mathrm{CH}_{4}$ fluxes and environmental variables (soil temperature, water table depth fluctuations) as well as additional features of individual collars were evaluated by Spearman's rank correlation (Table 2). A response of $\mathrm{CH}_{4}$ emissions to the investigated environmental variables was identified only for a few individual collars (see the Supplement). Therefore, no seasonal or annual ecosystem emissions were calculated. Statistical analyses were performed using MATLAB (MATLAB Statistics Toolbox Release R2017a). All flux data were reported as mean \pm standard deviation.

\subsection{Depth profiles of peat pore water concentrations}

\subsubsection{Sampling and field measurements}

Multilevel piezometers (MLPs), as described in Beer and Blodau (2007), were installed during both measurement campaigns in austral summer 2015 and 2016 to determine pore water concentrations in depth profiles. The MLPs provided a spatial sampling resolution of either 0.1 or $0.2 \mathrm{~m}$ and were equipped with diffusive equilibration samplers made of permeable silicone tubes providing a $4 \mathrm{~mL}$ gas sample volume together with a $5 \mathrm{~mL}$ crimp vial filled with deionized water and covered with a permeable membrane (Supor 200 $0.2 \mu$, Pall Corporation, Pall Life Sciences). To collect gas samples, MLPs were stepwise retrieved and the gas volume extracted from the equilibration sampler with a $3 \mathrm{~mL}$ syringe was transferred into nitrogen-flushed $5 \mathrm{~mL}$ crimp vials. The 
Table 1. Characteristic plant species of dominant microforms in a Patagonian cushion bog. Species composition was determined during the second measurement campaign within collars where closed chamber measurements were conducted. Mean cover (\%) and its standard deviation of characteristic were given and plant species with a mean cover $<5 \%$ were listed with + .

\begin{tabular}{|c|c|c|c|}
\hline Species & Astelia lawn & $\begin{array}{c}\text { Microform } \\
\text { Sphagnum lawn }\end{array}$ & Donatia lawn \\
\hline Astelia pumila & $84 \pm 16$ & & \\
\hline Donatia fascicularis & $8 \pm 10$ & + & $90 \pm 9$ \\
\hline Sphagnum magellanicum & & $94 \pm 4$ & \\
\hline Tetroncium magellanicum & + & $7 \pm 2$ & + \\
\hline Caltha dioneifolia & + & + & $6 \pm 5$ \\
\hline Empetrum rubrum & + & & \\
\hline Gaultheria antarctica & + & + & + \\
\hline Myrteola nummularia & + & & \\
\hline
\end{tabular}

crimp vials were capped with a butyl stopper with an aluminium crimp seal. MLPs were installed in Astelia lawns and pools in three replicates at each platform where closed chamber measurements were performed.

In January 2015, MLPs were installed in Astelia lawns $(0.2 \mathrm{~m}$ resolution, $2 \mathrm{~m}$ depth) and pools $(0.1 \mathrm{~m}$ resolution from 0 to $1 \mathrm{~m}$ in depth, $0.2 \mathrm{~m}$ resolution below down to a maximum depth of $4 \mathrm{~m}$ ) for 5 weeks of equilibration time. From gas samples pore water concentrations of $\mathrm{CH}_{4}$, DIC and hydrogen $\left(\mathrm{H}_{2}\right)$ were determined. To measure sulfate concentrations, which are potential electron acceptors originating from sea spray and affecting competitiveness of methanogenesis (Broder et al., 2015), a pore water subsample obtained from each crimp vial was transferred to a storage vial and stored frozen until analysis. An aliquot of each remaining pore water sample was measured in situ with a $\mathrm{pH} / \mathrm{EC}$ (electrical conductivity) meter (Combo HI 98129/130, Hannah Instruments, Germany).

In January 2016, MLPs were installed to a depth of $3 \mathrm{~m}$ in pools (resolution as in 2015) for 3 weeks of equilibration time and afterwards again in Astelia lawns $(0.1 \mathrm{~m}$ resolution in transition zone from rooted to non-rooted peat at $1-2 \mathrm{~m}$ in depth) for 9 weeks of equilibration time. In 2016, equilibration samplers were used to collect $\mathrm{CH}_{4}$ and $\mathrm{CO}_{2}$ samples and determine their carbon stable isotopic signatures. Pore water samples obtained from crimp vials were used to measure $\mathrm{O}_{2}$ concentrations in situ with a planar trace oxygen minisensor (Fibox 3, PreSens Precision Sensing GmbH, Germany).

\subsubsection{Analytical procedures}

Gas samples were transported to Germany and analysed within 4 weeks. Gaseous $\mathrm{CH}_{4}$ and $\mathrm{CO}_{2}$ concentrations were measured with a gas chromatograph (8610C, SRI Instruments, USA) equipped with a methanizer and flame ionization detector (FID). Hydrogen concentrations were analysed on a $\mathrm{H}_{2}$ analyser (Ametek ta3000 $\mathrm{H}_{2}$ analyser, Trace Analytical TA 3000r). Sulfate concentrations were obtained by ion chromatography (883 Basic IC plus, Metrohm, Herisau, Switzerland).

Stable carbon isotopic signatures of $\mathrm{CH}_{4}$ and $\mathrm{CO}_{2}$ were simultaneously determined by cavity ring-down spectroscopy (CRDS; Picarro G2201-i connected to a small sample isotope module (SSIM, model A0314), Picarro Inc., USA). As this set-up required a minimum sample volume of $20 \mathrm{~mL}$, samples were diluted with nitrogen prior to measurements. The instrument was calibrated in the beginning of every measurement day using two working standards of $\mathrm{CH}_{4}(1000 \mathrm{ppm}$, $-42.48 \%$ o ) and $\mathrm{CO}_{2}(1000 \mathrm{ppm},-31.07 \%$ ). Isotopic signatures are given in $\delta$ notation relative to Vienna Peedee Belemnite (VPDB). As samples were stored for several weeks and $\delta^{13} \mathrm{C}-\mathrm{CO}_{2}$ values were biased in case of high $\mathrm{CH}_{4}$ concentrations in the sample, a correction procedure was applied following Berger et al. (2018).

\subsubsection{Calculations and statistical analyses}

Pore water concentrations of $\mathrm{CH}_{4}$, DIC and $\mathrm{H}_{2}$ were recalculated from gaseous concentrations obtained from equilibration samplers by applying Henry's law following Eq. (1):

$c=K_{\mathrm{H}} \cdot p$,

where $c$ is the concentration in moles per litre, $p$ the pressure in atmospheres and $K_{\mathrm{H}}$ the Henry constant that was corrected according to Sander (1999) for mean soil temperatures of $10^{\circ} \mathrm{C}$ in February 2015 and 2016 as well as $7{ }^{\circ} \mathrm{C}$ in April at a depth of $0.5 \mathrm{~m}$. DIC concentrations at prevalent $\mathrm{pH}$ conditions were calculated with respect to carbonate speciation considering equilibrium constants following Stumm and Morgan (1996). All pore water data were reported as mean \pm standard deviation $(\mathrm{N}=3)$.

Zones of $\mathrm{CH}_{4}$ production and consumption in the peat column were visually identified based on observed pore water concentration gradients. For a quantitative evaluation of pore water concentration gradients, steady-state conditions as well as a dominance of diffusive gas transport would have to be assumed; this may only partly apply to the system under 


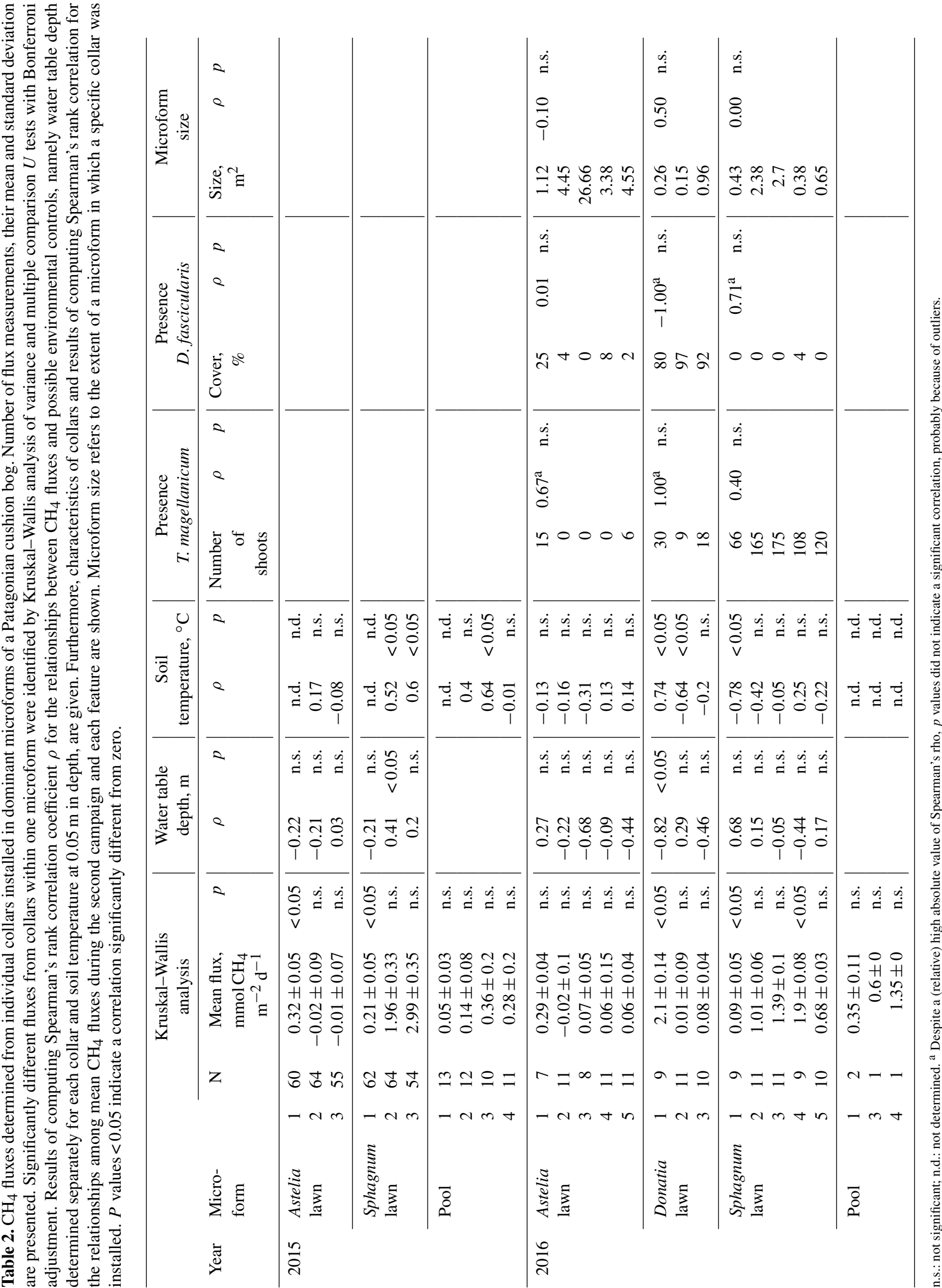


study here, given the large root biomass. Nevertheless, we additionally applied a software routine using inverse modelling (PROFILE, Berg et al., 1998) for zone identification. This modelling approach supported the results obtained visually, but provided further rough estimates for production and consumption zones due to the complex diffusivity in the rhizosphere of highly rooted peat and, thus, results are presented in the Supplement only.

An apparent isotopic fractionation factor $\alpha_{\mathrm{c}}$ was determined (Whiticar et al., 1986; Hornibrook et al., 2000) to assess the predominant methanogenic pathway and / or methanotrophic activity following Eq. (2):

$\alpha_{\mathrm{c}}=\frac{\delta^{13} \mathrm{C}_{\mathrm{CO}_{2}}+1000}{\delta^{13} \mathrm{C}_{\mathrm{CH}_{4}}+1000}$.

\section{Results}

\subsection{Characteristics of solid peat and root biomass}

Roots of A. pumila were present in the upper profile down to a depth of $1.8 \mathrm{~m}$ (rhizosphere) in Astelia lawn cores. Throughout the rhizosphere, we observed a highly decomposed and amorphous peat supposedly originating from A. pumila that developed above Sphagnum peat. Peat below Sphagnum lawns was continuously formed predominantly by Sphagnum. Total C and N contents in the peat together with natural abundance of ${ }^{15} \mathrm{~N}$ and ${ }^{13} \mathrm{C}$ are given in Table 3. Root density of D. fascicularis was $0.014 \pm$ $0.010 \mathrm{~g} \mathrm{DW} \mathrm{L}$ of peat ${ }^{-1}$ at $0.35 \mathrm{~m}$ in depth while root density of A. pumila was not determined once again as it has been already quantified with $>4 \mathrm{~g} \mathrm{DW} \mathrm{L}$ of peat ${ }^{-1}$ at around $0.5 \mathrm{~m}$ in depth (Fritz et al., 2011).

\subsection{Environmental conditions and potential controls on $\mathrm{CH}_{4}$ fluxes}

The study site was characterized by daily mean PAR values up to $\sim 700 \mu \mathrm{mol} \mathrm{m}^{-2} \mathrm{~s}^{-1}$ with maximum values exceeding $2000 \mu \mathrm{mol} \mathrm{m}^{-2} \mathrm{~s}^{-1}$ and daily mean air temperatures ranging from $-0.5^{\circ} \mathrm{C}$ to $17^{\circ} \mathrm{C}$ during the measurement campaigns in austral summer from January to April (Fig. 2). Soil temperature in summer reached maximum daily average values of 15 and $12^{\circ} \mathrm{C}$ at $0.05 \mathrm{~m}$ in depth and $0.5 \mathrm{~m}$ in depth, respectively. Concurrently, the water table fluctuated close to the surface between -0.03 and $-0.23 \mathrm{~m}$ and differed consistently by about a few centimetres between the two water table measurement sites in Astelia lawns. $\mathrm{CH}_{4}$ fluxes approached zero in many cases, but differed significantly from zero down to absolute values of $0.01 \mathrm{mmol} \mathrm{CH}_{4} \mathrm{~m}^{-2} \mathrm{~d}^{-1}$. Fluxes below absolute values of $0.01 \mathrm{mmol} \mathrm{CH}_{4} \mathrm{~m}^{-2} \mathrm{~d}^{-1}$ did not differ significantly from zero and were therefore set to zero. For collars exhibiting low-magnitude fluxes neither seasonal trends (data not shown) nor a relationship to water table and soil
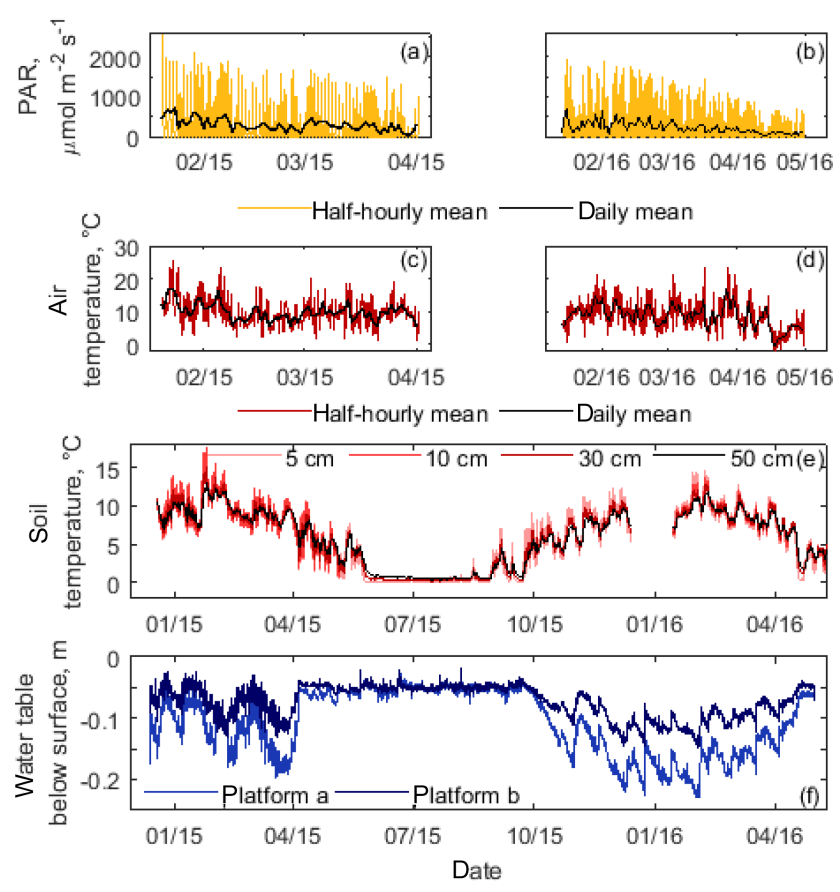

Figure 2. Time series of environmental variables during the study period. Photosynthetic active radiation (PAR, a, b) and air temperature (c, d) are presented as half-hourly and daily means during two austral summer periods. Soil temperature (e) and water table position below the surface (f) were continuously recorded and are shown as half-hourly means. Note the difference in response time between platform a and platform $b$ where water table fluctuations were recorded.

temperature fluctuations could be identified (Table 2). Yet, significant relationships among water table fluctuations or variations in soil temperatures were established for those few lawns with considerable emissions (Table 2).

\subsection{Soil-atmosphere $\mathrm{CH}_{4}$ fluxes and features of microforms possibly affecting $\mathrm{CH}_{4}$ emissions}

Summer $\mathrm{CH}_{4}$ emissions in a south Patagonian cushion bog were highly variable among the dominant microforms Astelia lawns, Sphagnum lawns and Donatia lawns characterized by specific plant species as well as pools and showed a pronounced spatial pattern even within microforms. Compared to all other microforms, only Sphagnum lawns showed considerable emissions with $1.52 \pm 1.10 \mathrm{mmol} \mathrm{CH}_{4} \mathrm{~m}^{-2} \mathrm{~d}^{-1}$ while Astelia lawns emitted nearly no $\mathrm{CH}_{4}$ with $0.09 \pm$ $0.16 \mathrm{mmol} \mathrm{m}^{-2} \mathrm{~d}^{-1}$ (Fig. 3). Methane emissions from pools were also low $\left(0.23 \pm 0.25 \mathrm{mmol} \mathrm{m}^{-2} \mathrm{~d}^{-1}\right)$ and not significantly different from intermediate Donatia lawn fluxes $\left(0.66 \pm 0.96 \mathrm{mmol} \mathrm{CH}_{4} \mathrm{~m}^{-2} \mathrm{~d}^{-1}\right)$. During some occasions, we determined even significant, negative $\mathrm{CH}_{4}$ fluxes, mainly from Astelia lawns (Fig. 3a, Table 2). Most of these negative fluxes as well as the majority of fluxes $(41 \%)$ that were set to zero were obtained from one individual collar throughout 
Table 3. Summary of peat characteristics obtained from two peat cores taken in Astelia lawns in a Patagonian cushion bog. Data were averaged over the respective depths sampled at $0.1 \mathrm{~m}$ resolution.

\begin{tabular}{|c|c|c|c|c|c|c|c|}
\hline Peat characteristics & $\begin{array}{r}\text { Depth, } \\
\mathrm{m}\end{array}$ & $\begin{array}{l}\text { Bulk density, } \\
\mathrm{g} \mathrm{cm}^{-3}\end{array}$ & $\mathrm{~N}, \%$ & C, $\%$ & $\mathrm{C} / \mathrm{N}$ & $\delta^{15} \mathrm{~N}$ & $\delta^{13} \mathrm{C}$ \\
\hline $\begin{array}{l}\text { Amorphous, highly decomposed cushion } \\
\text { peat with many living Astelia } \\
\text { roots, only close to the surface }(0-0.4 \mathrm{~m}) \\
\text { with recognizable plant material }\end{array}$ & $0-1$ & 0.03 & 1.42 & 49.31 & 37.62 & -1.24 & -25.63 \\
\hline \multirow{6}{*}{$\begin{array}{l}\text { Sphagnum peat, with depth } \\
\text { increasingly amorphous and decomposed }\end{array}$} & $1-2$ & 0.06 & 1.83 & 52.45 & 28.69 & 1.24 & -26.18 \\
\hline & $2-3$ & 0.06 & 1.52 & 51.37 & 34.38 & 1.12 & -26.33 \\
\hline & $3-4$ & 0.06 & 1.22 & 50.49 & 41.98 & 0.22 & -25.78 \\
\hline & $4-5$ & 0.11 & 1.17 & 47.86 & 41.45 & -1.59 & -26.43 \\
\hline & $5-6$ & 0.10 & 1.18 & 47.56 & 40.67 & -1.62 & -26.77 \\
\hline & $6-7$ & 0.15 & 1.28 & 50.27 & 44.34 & -1.97 & -27.08 \\
\hline
\end{tabular}

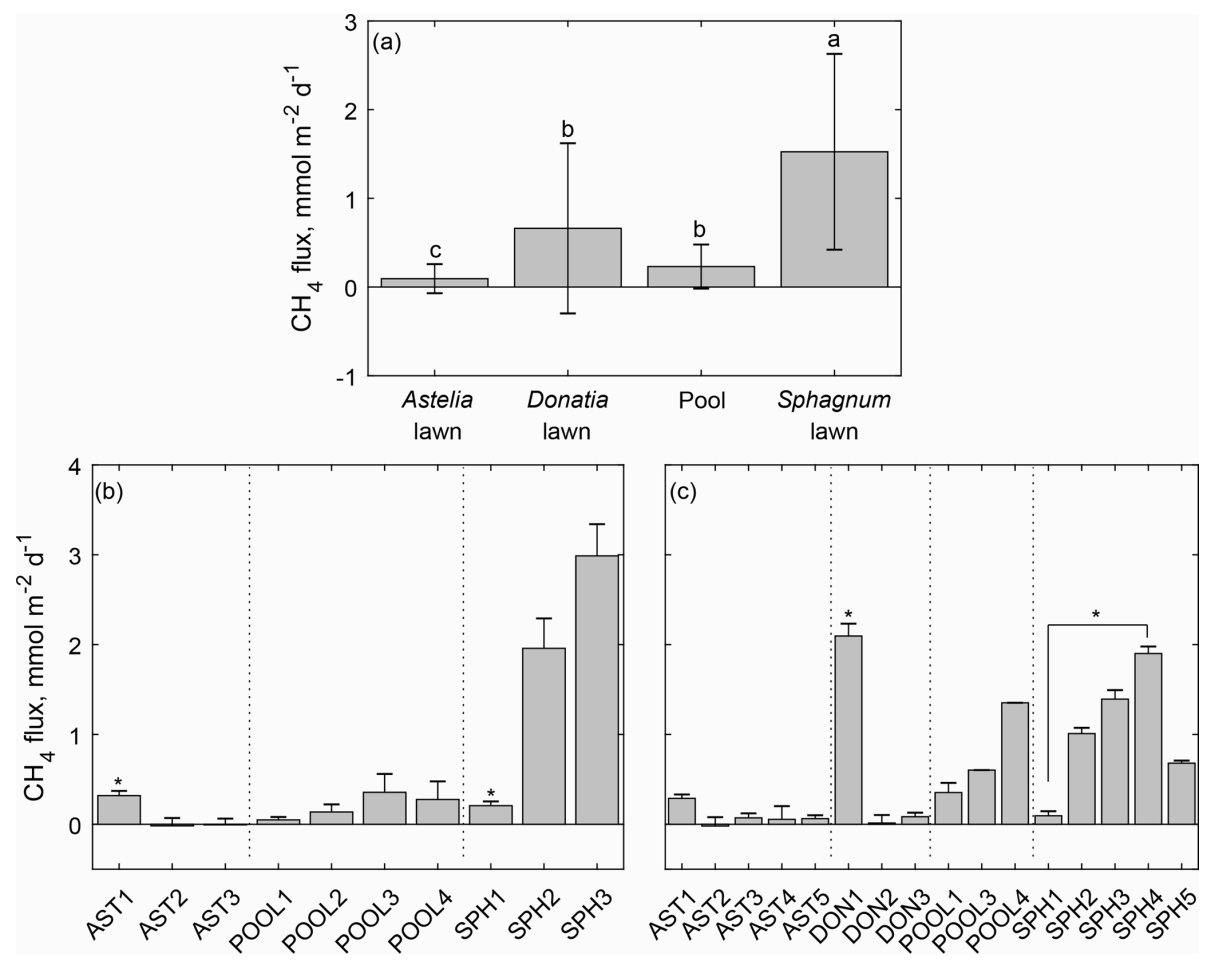

Figure 3. Mean $\mathrm{CH}_{4}$ emissions and their standard deviation determined from dominant microforms (a) and individual collars during the two measurement campaigns $(\mathbf{b}, \mathbf{c})$ in a Patagonian cushion bog. Different letter superscripts denote significantly different amounts of emitted $\mathrm{CH}_{4}$ among microforms despite variability within microforms being substantial (a) or from collars within one microform (b, c) that were identified by Kruskal-Wallis analysis of variance and multiple comparison $U$ tests with Bonferroni adjustment.

the whole measurement campaign precluding the possibility of a measurement artefact.

As indicated by high standard deviations, $\mathrm{CH}_{4}$ emissions among replicates of all microforms were not consistent. Field observations suggested that $\mathrm{CH}_{4}$ emissions of a microform were not only controlled by the predominant plant species, but might also have been associated with additional features of the respective microform. Therefore additional microform features (i.e. number of T. magellanicum shoots, cover of $D$. fascicularis, extent of the microform in which a specific collar was installed) were assessed. However, as we did not expect such small-scale spatial variability among emissions of individual collars, the results of this survey given in Table 2 are of rather explorative, preliminary character as the low number of replicates (three to five collars) in combination with several outliers barely allows any sound statistical analysis. Nevertheless, collars with elevated or comparatively high emissions had some fea- 
tures in common: emissions from one Astelia lawn were with $\sim 0.3 \mathrm{mmol} \mathrm{CH}_{4} \mathrm{~m}^{-2} \mathrm{~d}^{-1}$, (significantly) higher in both sampling years compared to fluxes measured from the other Astelia lawns. This Astelia lawn collar with elevated emissions was characterized by (i) the presence of many T. magellanicum shoots together with a high share of D. fascicularis and (ii) placed in a lawn with small extent surrounded by a mosaic of small pools and $D$. fascicularis patches (both smaller than $1 \mathrm{~m}^{2}$ ). Surprisingly, one Donatia lawn was also a substantial $\mathrm{CH}_{4}$ source of $2.10 \pm 0.14 \mathrm{mmol} \mathrm{m}^{-2} \mathrm{~d}^{-1}$, even exceeding the highest emissions observed from Sphagnum lawns on all measurement occasions in 2016. Similar to the Astelia lawn with elevated emissions, the collars of Donatia and Sphagnum lawns with high emissions were characterized by (i) a high number of T. magellanicum shoots and (ii) placed in lawns surrounded by small pools and other patches of $D$. fascicularis with no A. pumila nearby. Emissions obtained from one Sphagnum lawn were, with less than $0.3 \mathrm{mmol} \mathrm{CH}_{4} \mathrm{~m}^{-2} \mathrm{~d}^{-1}$ in both sampling years, significantly lower compared to emissions from other Sphagnum lawns. Vice versa, this collar with low Sphagnum emissions was characterized by (i) the lowest number of T. magellanicum shoots among all Sphagnum lawn collars and (ii) installed in a small Sphagnum lawn surrounded by A. pumila.

\subsection{Pore water $\mathrm{CH}_{4}$ and DIC concentration profiles}

Pore water profiles in peat columns below Astelia lawns and pools showed similar trends in pore water concentrations and during both sampling years. $\mathrm{CH}_{4}$ concentrations were almost zero in the upper pore water profile below Astelia lawns $\left(<0.003 \mathrm{mmol} \mathrm{L}^{-1}\right)$ down to a depth of around $1.5 \mathrm{~m}$, which corresponds to the zone where the rhizosphere was most pronounced (Fig. 4a). Below this depth, $\mathrm{CH}_{4}$ concentrations sharply increased up to $0.25 \pm 0.08 \mathrm{mmol} \mathrm{L}^{-1}$ at $3 \mathrm{~m}$ in depth. $\mathrm{CH}_{4}$ concentrations in pore water profiles below pools resembled profiles obtained under Astelia lawns on elevated levels. Throughout the upper profile down to $1.5 \mathrm{~m}, \mathrm{CH}_{4}$ concentrations were $\sim 0.03 \mathrm{mmol} \mathrm{L}^{-1}$ with a peak around $0.3 \mathrm{~m}$ in depth $\left(0.06 \pm 0.06 \mathrm{mmol} \mathrm{L}^{-1}\right)$ and increased steeply to $0.40 \pm 0.25 \mathrm{mmol} \mathrm{L}^{-1}$ at $3 \mathrm{~m}$ in depth. Maximum concentrations in comparable depths reached similar levels in both sampling years below Astelia lawns, but maximum concentrations below pools were about 3 times higher in 2015 compared to 2016.

DIC predominantly occurred as dissolved $\mathrm{CO}_{2}$ because of the low $\mathrm{pH}$ ranging from 3.36 to 4.77 . Contrary to $\mathrm{CH}_{4}$, DIC concentrations increased constantly with depth from around $1 \mathrm{mmol} \mathrm{L}^{-1}$ near the surface to $2.60 \pm 1.0 \mathrm{mmol} \mathrm{L}^{-1}$ at $2 \mathrm{~m}$ in depth below Astelia lawns and $2.94 \pm 1.1 \mathrm{mmol} \mathrm{L}^{-1}$ at $3 \mathrm{~m}$ in depth below pools (Fig. 4b). With depth, DIC converged with $\mathrm{CH}_{4}$ concentrations, which was reflected by DIC : $\mathrm{CH}_{4}$ ratios that were extremely high in the rhizosphere below Astelia lawns exceeding 100 (Fig. 4c). Beneath the rhizosphere, ratios steeply approached values below 40 . Under pools, ra- tios slightly decreased with depth but were mostly around 40 down to $1.5 \mathrm{~m}$ with two distinct peaks of very little $\mathrm{CH}_{4}$ at the surface and around $0.8 \mathrm{~m}$ in depth. In deep peat layers below the rhizosphere, DIC : $\mathrm{CH}_{4}$ ratios detected under Astelia lawns and pools converged and reached the lowest ratios of $\sim 10$ and $\sim 5$, respectively.

Visual inspection of concentration profiles but also modelling of $\mathrm{CH}_{4}$ production and consumption rates indicated a predominance of $\mathrm{CH}_{4}$ consumption throughout the whole rhizosphere below Astelia lawns and in roughly corresponding depths under pools (Figs. 4a, 6). Maximum $\mathrm{CH}_{4}$ consumption was identified in the lower rhizosphere around 1.5$2 \mathrm{~m}$ where the increase in $\mathrm{CH}_{4}$ concentration was most pronounced. Deep peat layers below the rhizosphere of Astelia lawns and similar depths below pools were considered to be $\mathrm{CH}_{4}$ sources. In these depths, the high concentration levels of $\mathrm{CH}_{4}$ (up to $0.40 \pm 0.25 \mathrm{mmol} \mathrm{L}^{-1}$ ) sustain substantial upward diffusion of $\mathrm{CH}_{4}$ following the concentration gradient into the consumption zone throughout the rhizosphere of Astelia lawns and in corresponding depths below pools.

\subsection{Carbon isotopic values in pore water and apparent fractionation}

Values of $\delta^{13} \mathrm{C}_{\text {in }} \mathrm{CH}_{4}$ did not show a clear depth trend below Astelia lawns and ranged in the upper profile down to $2 \mathrm{~m}$ in depth between $-87.2 \pm 10.1$ and $-72.1 \pm 10.3 \%$ (Fig. 4d). Isotopic $\delta^{13} \mathrm{C}-\mathrm{CH}_{4}$ values below pools became less negative with depth from $-93.4 \pm 9.2$ to $-73.7 \pm 1.2 \%$, with a minimum peak in the upper peat layers around $0.3 \mathrm{~m}$ of $-101.0 \pm 5.6 \%$. In the upper metre of the profile, values of $\delta^{13} \mathrm{C}-\mathrm{CH}_{4}$ were thus up to $25 \%$ more negative below pools compared to Astelia lawns while the isotopic values of both profiles converged in deep peat layers below $2 \mathrm{~m}$ at $-80 \%$. Values of $\delta^{13} \mathrm{C}$ in $\mathrm{CO}_{2}$ below Astelia lawns became more negative with depth in the upper profile down to $1 \mathrm{~m}$, reaching values as low as $-32.4 \pm 0.8 \%$, and increased to $-19.5 \pm 1.0 \%$ at $3 \mathrm{~m}$ in depth. Below pools, values became less negative with depth throughout the whole profile from $-21.2 \pm 0.4$ to $-6.0 \pm 1.5 \%$ (Fig. $4 \mathrm{e}$ ).

Apparent fractionation factors varied only slightly and showed opposite trends below the two microforms. Values increased slightly from 1.060 to 1.066 below Astelia lawns, peaking at 1.045 at $0.5 \mathrm{~m}$ in depth. Below pools, apparent fractionation factors decreased with depth from 1.079 to 1.073 with a maximum of 1.091 around $0.3 \mathrm{~m}$ in depth (Fig. 4f).

\subsection{Hydrogen, oxygen and sulfate concentrations in pore water profiles}

Hydrogen concentrations were mostly below $3 \mathrm{nmol} \mathrm{L}^{-1}$ below Astelia lawns while they were elevated below pools, ranging between 3 and $10 \mathrm{nmol} \mathrm{L}^{-1}$ (Fig. 5a). Maximum concentrations were reached in the upper profile of Astelia 

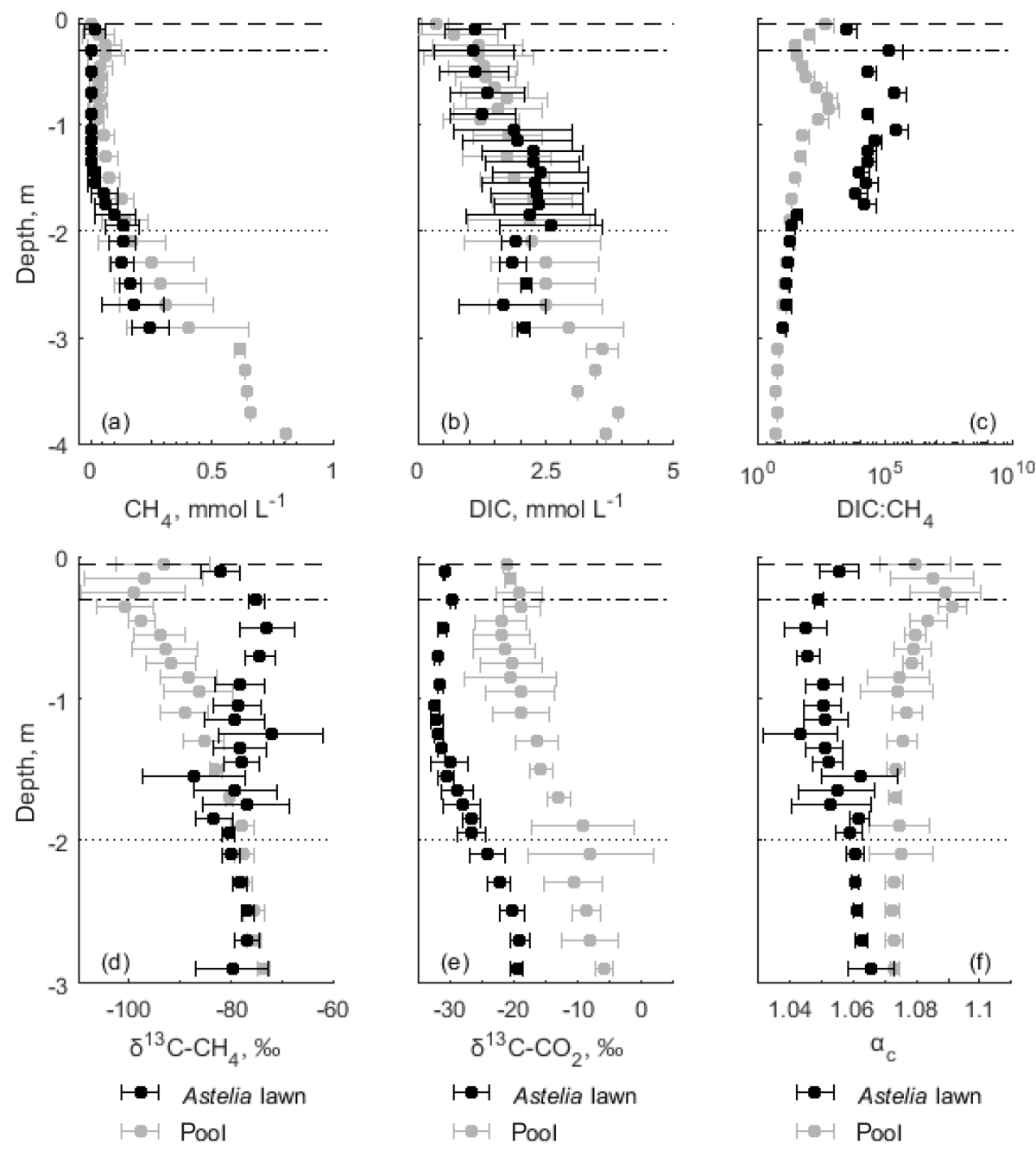

- Water table ....... Lower boundary rhizosphere.-- . Pool bottom

Figure 4. Pore water composition in depth profiles obtained from MLPs $(\mathrm{N}=3)$ installed in Astelia lawns and pools during two sampling campaigns in austral summer in 2015 and 2016. Mean values and their standard deviation are presented. $\mathrm{CH}_{4}$ (a) and DIC (b) concentrations as well as related DIC : $\mathrm{CH}_{4}$ (c) ratios were determined during both sampling events while carbon isotope values of $\mathrm{CH}_{4}(\mathbf{d})$ and DIC $(\mathbf{e})$ and corresponding fractionation factors (f) were investigated only during the second campaign. DIC : $\mathrm{CH}_{4}$ ratios are shown on a logarithmic scale without negative standard deviation for Astelia lawns and pools. Displayed depths represent the centre of a MLP segment and had to be standardized because of different sampling resolution in both years. The water table position and approximate maximum rooting depth (rhizosphere) refer to Astelia lawns only. Note the different scale of the $y$ axis in the upper and lower three panels.

lawns with up to $11.83 \pm 17.88 \mathrm{nmol} \mathrm{L}^{-1}$ and, in addition to a peak at the surface, below pools from 1 to $2 \mathrm{~m}$ in depth with up to $41.61 \pm 64.63 \mathrm{nmol} \mathrm{L}^{-1}$. Molecular oxygen concentrations were mostly below $5 \%$ saturation and tended to be higher in the upper profile down to $2 \mathrm{~m}$ below Astelia lawns compared to pools (Fig. 5b). Sulfate concentrations were similar below both, Astelia lawns and pools, and reached the highest values near the surface with up to $16.43 \pm 11.85 \mu \mathrm{mol} \mathrm{L}^{-1}$. With depth, concentrations decreased and approached zero below $1 \mathrm{~m}$ (Fig. 5c).

\section{Discussion}

This study is among the first dealing with $\mathrm{CH}_{4}$ dynamics in an austral, vascular-plant-dominated cushion bog. We aimed to reveal patterns of $\mathrm{CH}_{4}$ emissions and their environmental as well as potential below-ground biogeochemical controls. We furthermore attempted to elucidate the $\mathrm{CH}_{4}$ dynamics in the peat below the four predominant microforms on a conceptual level based on the results presented here and in previous studies. 

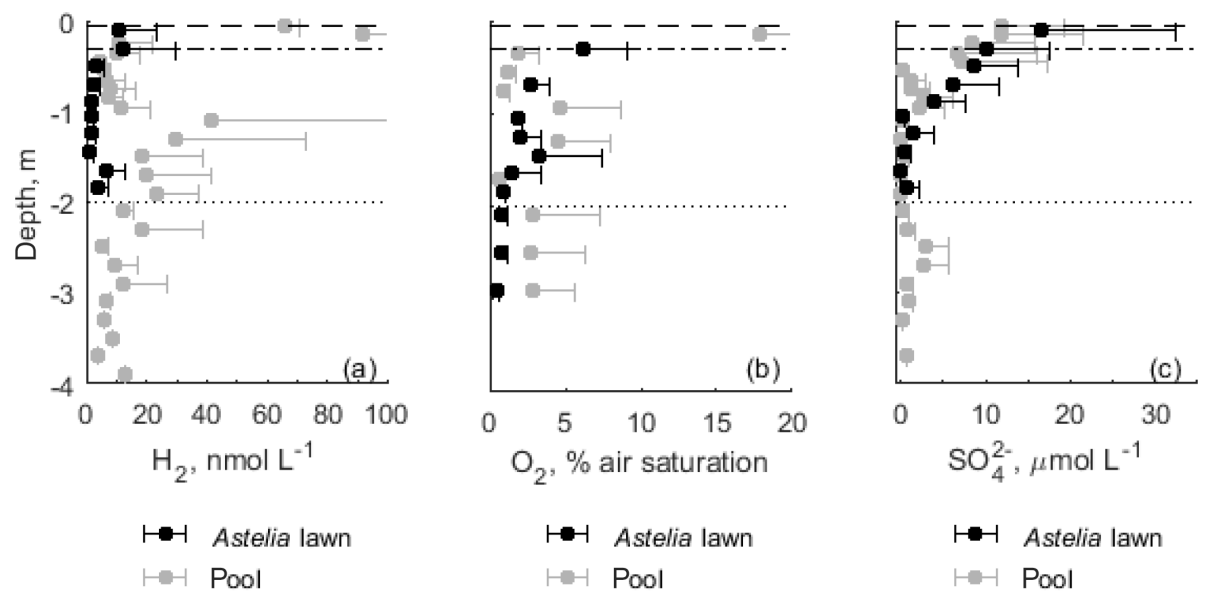

- Water table ....... Lower boundary rhizosphere -... Pool bottom

Figure 5. Profiles of $\mathrm{H}_{2}(\mathbf{a}), \mathrm{O}_{2}(\mathbf{b})$ and sulfate (c) pore water concentrations obtained from MLPs $(\mathrm{N}=3)$ installed in Astelia lawns and pools during two sampling campaigns in austral summer in 2015 and 2016. Mean values and their standard deviation are presented. Displayed depths represent the centre of a MLP segment and had to be standardized because of different sampling resolution in both years. The water table position and approximate maximum rooting depth (rhizosphere) refer to Astelia lawns only.

\subsection{Environmental controls on $\mathrm{CH}_{4}$ emissions}

Summer $\mathrm{CH}_{4}$ emissions of a south Patagonian cushion bog dominated by A pumila were low, albeit spatial heterogeneity was pronounced with small patches of Sphagnum or Donatia lawns being local emission hotspots. The variation in $\mathrm{CH}_{4}$ fluxes was mainly controlled by the dominant plant species of each lawn microform, which emitted significantly different amounts of $\mathrm{CH}_{4}$. We found only a few significant responses of $\mathrm{CH}_{4}$ fluxes to water table fluctuations or variations in soil temperatures (Table 2). Such weak coupling between environmental variables and $\mathrm{CH}_{4}$ emissions is not surprising as fluxes from most individual collars were relatively low. Furthermore, the water table fluctuated only slightly near the surface (Fig. 2) and may thus not serve as a primary control on $\mathrm{CH}_{4}$ emissions. Stronger effects may only be expected when amplitude and duration of fluctuations affect peat redox conditions substantially (Blodau and Moore, 2003; Knorr et al., 2009). Under such stable moisture conditions and as long as methanogenesis is not limited by substrate supply, the sensitivity of methanogenic microbial consortia to temperature should become apparent (Whalen, 2005). Variations in landscape $\mathrm{CH}_{4}$ fluxes have indeed been related to soil temperature previously (Rinne et al., 2007; Jackowicz-Korczyński et al., 2010; Goodrich et al., 2015), which is in accordance with the present study. The temporal variability in $\mathrm{CH}_{4}$ emissions over the two investigated seasons was rather low (data not shown) due to low seasonality in both, temperature and precipitation, in the study region. Measurement campaigns extending over shoulder seasons and comparing years of contrasting weather conditions would be necessary to reveal the impact of more pro- nounced water table fluctuations or temperature regimes on $\mathrm{CH}_{4}$ fluxes in south Patagonian cushion bogs.

\subsection{Astelia lawns - zero emission scenario}

Emissions from Astelia lawns were minute (0.09 \pm $0.16 \mathrm{mmol} \mathrm{m}^{-2} \mathrm{~d}^{-1}$ ) and significantly lower than from all other microforms (Fig. 3), verifying our first hypothesis. The near-zero emissions were well explained by near-zero $\mathrm{CH}_{4}$ concentrations $\left(<0.003 \mathrm{mmol} \mathrm{L}^{-1}\right)$ in the rhizosphere down to around $1.8 \mathrm{~m}$. Only below, concentrations increased sharply to $0.2 \mathrm{mmol} \mathrm{L}^{-1}$ at $2 \mathrm{~m}$ in depth (Fig. 4a). The low $\mathrm{CH}_{4}$ concentrations even turned some Astelia lawns into a small sink for atmospheric $\mathrm{CH}_{4}$ as shown by negative fluxes that were obtained sporadically throughout the whole measurement campaign, confirming earlier results (Kip et al., 2012). These findings agree with previous research by Fritz et al. (2011), who observed $\mathrm{CH}_{4}$ emissions from Astelia lawns at a low magnitude compared to that presented here and presented a similar $\mathrm{CH}_{4}$ concentration depth profile. Extremely low $\mathrm{CH}_{4}$ concentrations have also been obtained by Dullo et al. (2017) in upper peat layers of an Ethiopian cushion bog. Nevertheless, in deep peat layers below the rhizosphere, $\mathrm{CH}_{4}$ concentrations of our study approached magnitudes reported for Chilean bogs with mixed vegetation consisting of Sphagnum mosses and A. pumila (Broder et al., 2015). This is in the lower range of concentrations described from northern bogs mostly around $0.5 \mathrm{mmol} \mathrm{L}-1$ (e.g. Blodau and Moore, 2003; Beer and Blodau, 2007; Beer et al., 2008; Corbett et al., 2013) but even reaching up to $5 \mathrm{mmol} \mathrm{L}^{-1}$ at comparable depths (Steinmann et al., 2008). 
A $\mathrm{CH}_{4}$ concentration profile as observed at our site suggests that in deep peat layers below the rhizosphere $(>2 \mathrm{~m})$ $\mathrm{CH}_{4}$ was produced at substantial rates and comparably low oxidation, as indicated by DIC : $\mathrm{CH}_{4}$ ratios notably smaller than 40 (Fig. 4c). Subsequently, $\mathrm{CH}_{4}$ became almost completely oxidized on its diffusive way to the atmosphere as visualized on a conceptual level (Fig. 6). Ratios of DIC : $\mathrm{CH}_{4}$ under methanogenic conditions in northern bogs are typically around 5 (e.g. Hornibrook et al., 1997; Blodau and Moore, 2003; Corbett et al., 2013), but can be as high as 30 (Steinmann et al., 2008). Notably higher ratios throughout the rhizosphere suggested methanotrophic activity and availability of either alternative electron acceptors or $\mathrm{O}_{2}$ from aerenchymous roots suppressing methanogenesis (Colmer, 2003; Mainiero and Kazda, 2005; Knorr et al., 2008a, Fritz et al., 2011; Dullo et al., 2017). Diffusion and plant-mediated transport as pathways for upward $\mathrm{CH}_{4}$ transport would have caused higher emissions and ebullition requires supersaturation of at least $\sim 350 \mathrm{mmol} \mathrm{CH}_{4} \mathrm{~L}^{-1}$ in the pore water (Fechner-Levy and Hemond, 1996; Beer et al., 2008). The sharp drop in $\mathrm{CH}_{4}$ concentrations from -2 to $-1.5 \mathrm{~m}$ in depth characterized this peat layer as a zone of the strongest methanotrophic activity, as supported by modelled consumption zones.

Carbon isotopic values obtained from pore water profiles reflected rhizosphere processes, although the $\delta^{13} \mathrm{C}-\mathrm{CH}_{4}$ signature alone did not provide a clear indication for oxidative effects in the rhizosphere as proposed in our second hypothesis. A strong effect of only methanotrophy should result in a shift of the mean $\delta^{13} \mathrm{C}-\mathrm{CH}_{4}$ signature to more enriched values and distinct changes in the fractionation factor from lower to upper horizons. Methane isotopic signatures were close to $-80 \%$ in deep peat layers while above $2 \mathrm{~m}$ in depth values ranged from -90 to $-70 \%$ o throughout the rhizosphere (Fig. 4d) while the fractionation factor increased slightly (Fig. 4f). These surprisingly negative $\delta^{13} \mathrm{C}-\mathrm{CH}_{4}$ values throughout the rhizosphere along with a comparatively small shift and a wider standard variation in replicate samples are an unexpected result that needs further explanation.

We can only explain the pronounced variation in replicate $\delta^{13} \mathrm{C}-\mathrm{CH}_{4}$ values to be associated with the presence of aerenchymous roots and the mean $\delta^{13} \mathrm{C}-\mathrm{CH}_{4}$ depth pattern by a coexistence of aerobic and anaerobic microsites that would both support such strong variation within short spatial scales. The occurrence of small-scale aerobic microsites attached to roots releasing $\mathrm{O}_{2}$ into water-saturated (peat) layers has been previously suggested (Colmer, 2003), also for peatlands in the Northern Hemisphere (Popp et al., 1999; Knorr et al., 2008a; Corbett et al., 2013). Life time and activity of $A$. pumila roots are highly dynamic (Knorr et al., 2015) and supposedly governed temporal and spatial expansion of microsites. Within these microsites, labile organic matter and $\mathrm{CH}_{4}$ were rapidly consumed by aerobic respiration and methanotrophy, resulting in $\mathrm{CH}_{4}$ enriched in ${ }^{13} \mathrm{C}$ by up to $10 \%$ (Fig. $4 \mathrm{~d}$ ). This $\delta^{13} \mathrm{C}-\mathrm{CH}_{4}$ signature and the apparently small ${ }^{12} \mathrm{C} /{ }^{13} \mathrm{C}$ fractionation observed throughout the rhizosphere (Fig. 4f) revealed the influence of a strongly fractionating process such as $\mathrm{CH}_{4}$ oxidation. Although based on ${ }^{13} \mathrm{C}$ isotope fractionation alone $\mathrm{CH}_{4}$ oxidation cannot be clearly separated from acetoclastic methanogenesis (Whiticar et al., 1986; Conrad, 2005), oxidative effects in the rhizosphere were very likely since diffusion or plant-mediated transport were excluded as sinks for $\mathrm{CH}_{4}$. Methanotrophy leaves $\mathrm{CH}_{4}$ in the pore water enriched by $\sim 10 \%$ while produced $\mathrm{CO}_{2}$ becomes depleted (Chasar et al., 2000; Popp et al., 1999) as observed here throughout the rhizosphere with fewer negative signatures occurring only at greater depths (Fig. 4e). Also, values of $\delta^{13} \mathrm{C}-\mathrm{CO}_{2}$ of less than $-30 \%$ o that were substantially lower than the source organic matter material around $-26 \%$ (Table 3 ) can only be explained by the influence of ${ }^{13} \mathrm{C}$-depleted carbon from oxidation of ${ }^{13} \mathrm{C}$-depleted $\mathrm{CH}_{4}$. Substantial rates of root respiration were a further source for depleted $\mathrm{CO}_{2}$ in the pore water (Corbett et al., 2013) as suggested by high DIC : $\mathrm{CH}_{4}$ ratios mostly exceeding 100 throughout the prevailingly watersaturated rhizosphere (Fig. 4c). Nevertheless, $\mathrm{O}_{2}$ release by roots still exceeded consumption, as demonstrated by $\mathrm{O}_{2}$ saturation reaching up to $10 \%$ (Fig. 5b). This $\mathrm{O}_{2}$ supply may thus not only fuel $\mathrm{CH}_{4}$ oxidation but also heterotrophic respiration using molecular oxygen or other electron acceptors regenerated by this $\mathrm{O}_{2}$ input (Colmer, 2003; Mainiero and Kazda; 2005). Likely further sources of $\mathrm{CO}_{2}$ could have been dissimilatory sulfate reduction in anaerobic microsites of surface peat layers down to $0.4 \mathrm{~m}$ (Fig. 5c) with sulfate originating from sea spray (Kleinebecker et al., 2008; Broder et al., 2015). Taking these results obtained from $\mathrm{CH}_{4}$ and DIC concentration profiles and their carbon isotopic signatures together, the second hypothesis stating that pore water concentrations below Astelia lawns reflect a distinct $\mathrm{CH}_{4}$ oxidation effect was confirmed.

Enriched $\mathrm{CH}_{4}$ being only a leftover from $\mathrm{CH}_{4}$ oxidation should result in a $\delta^{13} \mathrm{C}-\mathrm{CH}_{4}$ depth pattern following that of the $\delta^{13} \mathrm{C}-\mathrm{CO}_{2}$ profile (Hornibrook et al., 2000), but such a pattern was not observed in our study (Fig. 4d and e). The surprisingly negative $\delta^{13} \mathrm{C}-\mathrm{CH}_{4}$ signature throughout the rhizosphere is likely explained by production of small amounts of $\mathrm{CH}_{4}$ at anaerobic microsites in the absence of living roots. Either hydrogenotrophy or acetogenesis and subsequent acetoclastic methanogenesis cause large fractionation (Steinmann et al., 2008) and could add depleted $\mathrm{CH}_{4}$ to the rhizosphere. As we did not quantify other parameters such as labile organic root matter or root exudates and acetate concentrations or their carbon isotopic signatures, we cannot clearly determine the relative importance of both pathways for our study. Elevated $\mathrm{H}_{2}$ concentrations in surface peat layers (Fig. 5a) indicated high $\mathrm{H}_{2}$ production by fermentation compared to consumption by sulfate reduction or hydrogenotrophic methanogenesis, presumably due to high root litter input and root exudates (Knorr et al., 2009; EstopAragonés et al., 2013). But as acetogens can outcompete hy- 


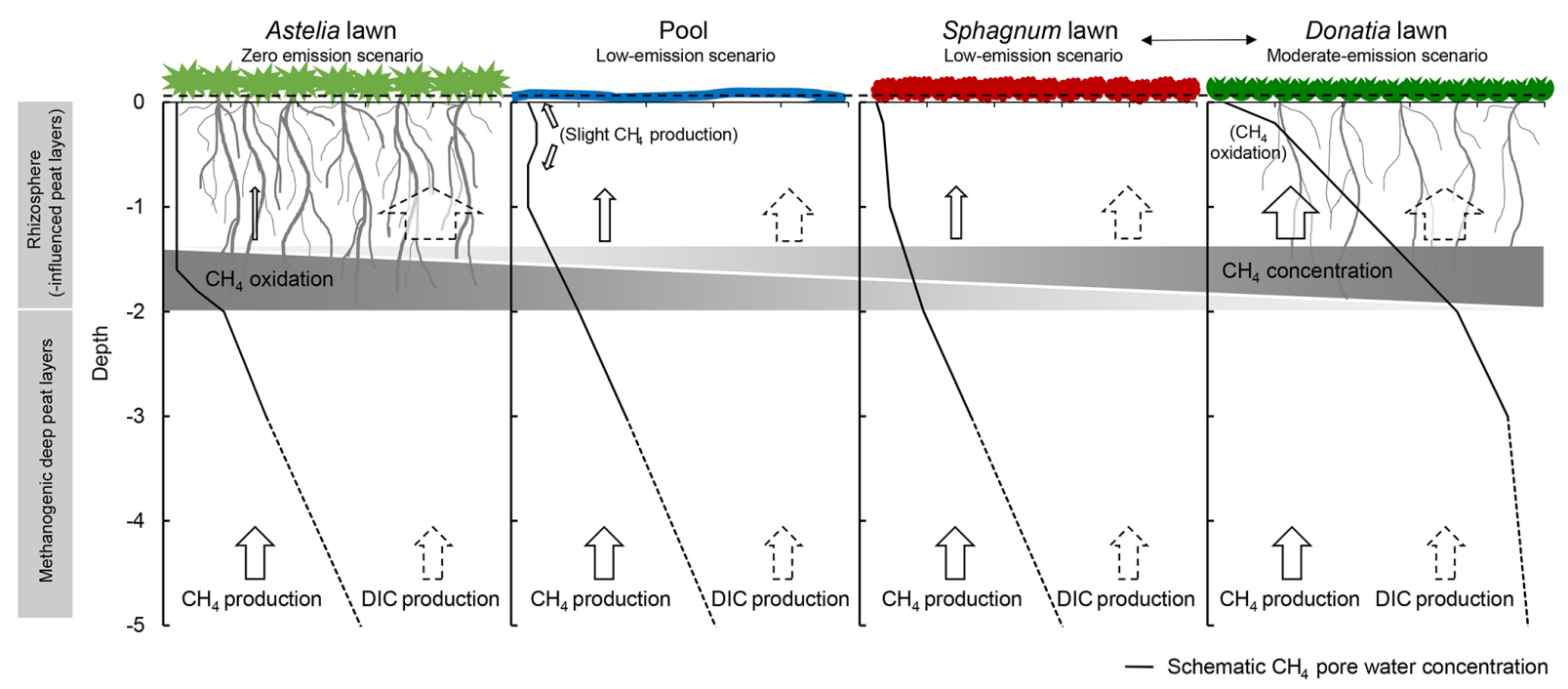

Figure 6. Schematic $\mathrm{CH}_{4}$ concentration profiles below the four dominant microforms in a Patagonian cushion bog. The shape of profiles was derived from data obtained in the present study together with those by Limpens et al. (2008), Fritz et al. (2011) and Broder et al. (2015). The size of arrows represents the relative magnitude of either a $\mathrm{CH}_{4}$ or $\mathrm{CO}_{2}$ flux following the diffusion gradient. The water table position is displayed by a dashed line near the surface. $\mathrm{CH}_{4}$ oxidation by root $\mathrm{O}_{2}$ release resulted in near-zero $\mathrm{CH}_{4}$ pore water concentrations in densely rooted peat below Astelia lawns. With increasing distance from densely rooted peat, $\mathrm{CH}_{4}$ oxidation decreased while $\mathrm{CH}_{4}$ concentration increased until reaching a depth profile typical for those of northern peatlands with fewer if any roots in water-saturated peat layers. Exemplary sequence of microforms, derived from observed amounts of emitted $\mathrm{CH}_{4}$. Other sequences of microforms are reasonable as microforms occur in various combinations in the field.

drogenotrophic methanogens at low temperatures, especially when $\mathrm{H}_{2}$ is available, (Kotsyurbenko et al., 2001), we propose that acetoclastic methanogenesis was the more important pathway here. Together with the probably high amounts of labile organic matter available to serve as substrate for methanogenesis throughout $2 \mathrm{~m}$ of rhizosphere, this explanation would support our third hypothesis. With depth, root density presumably decreased (Fritz et al., 2011) and a slight increase in ${ }^{12} \mathrm{C} /{ }^{13} \mathrm{C}$ fractionation indicated a shift to a predominance of hydrogenotrophic methanogenesis and, below $2 \mathrm{~m}$ in depth, absence of microsites (Fig. 4f) as $\alpha_{\mathrm{c}}$ values of replicate samples varied less and increased towards 1.065 (Whiticar et al., 1986; Conrad, 2005).

\subsection{Pools - low-emission scenario}

Pools exhibited, with $0.23 \pm 0.25 \mathrm{mmol} \mathrm{CH}_{4} \mathrm{~m}^{-2} \mathrm{~d}^{-1}$, the second lowest emissions of the microforms under study (Fig. 3). Such low emissions were contrary to our first hypothesis and somewhat surprising since they have been previously reported to be similar to Sphagnum lawns (Fritz et al., 2011) and were expected to be relevant $\mathrm{CH}_{4}$ sources because of prevailing anoxic conditions (Blodau, 2002). Moreover, other studies identified pools as hotspots of $\mathrm{CH}_{4}$ emissions from peatlands (Hamilton et al., 1994; Pelletier et al., 2014; Burger et al., 2016). This was clearly not the case here, as emissions were of the same order of magnitude as pool fluxes in south Patagonian Sphagnum bogs (Lehmann et al., 2016).
Low emissions were associated with $\mathrm{CH}_{4}$ pore water concentrations surprisingly resembling those below Astelia lawns on slightly elevated levels (Fig. 4a). These low pore water concentrations in sparsely or even non-rooted peat below pools were not supported by our second hypothesis and require another explanation. The $\delta^{13} \mathrm{C}_{-} \mathrm{CH}_{4}$ signature was depleted compared to Astelia lawns down to $2 \mathrm{~m}$ in depth and largely followed that of $\delta^{13} \mathrm{C}-\mathrm{CO}_{2}$ (Fig. $4 \mathrm{~d}$, e) and, thus, did not indicate a methanotrophic effect. As upward diffusion of $\mathrm{CH}_{4}$ against the concentration gradient is impossible, we can only explain low pore water concentrations by lateral exchange of $\mathrm{CH}_{4}$. We suggest that root $\mathrm{O}_{2}$ release by A. pumila controlled even $\mathrm{CH}_{4}$ dynamics below adjacent microforms as visualized on a conceptual level in Fig. 6. The thorough $\mathrm{CH}_{4}$ oxidation below Astelia lawns may establish a lateral concentration gradient of $\mathrm{CH}_{4}$. Thereby, $\mathrm{CH}_{4}$ from adjacent microforms may diffuse to the rhizosphere of Astelia lawns where it was consumed. As the microrelief is not pronounced at our study site, we propose that there is a large depth zone throughout the $2 \mathrm{~m}$ rhizosphere of Astelia lawns and in corresponding depths below pools with negligible water flow and a predominance of diffusive transport. In this depth zone, we observed a highly decomposed and amorphous peat as previously described for cushion bogs (Ruthsatz and Villagran, 1991; Fritz et al., 2011), indicating a very high water permeability that would together with a high water table position facilitate such lateral exchange (Baird et al., 2016). The assumption of lateral exchange was supported by a peak in 
DIC : $\mathrm{CH}_{4}$ ratios accompanied by very low $\mathrm{CH}_{4}$ concentrations around $0.8 \mathrm{~m}$ below pools (Fig. $4 \mathrm{c}$ ), inhibiting upward diffusion. Lateral root ingrowth and $\mathrm{O}_{2}$ supply from adjacent Astelia lawns could furthermore suppress methanogenesis and keep $\mathrm{CH}_{4}$ concentrations below pools low, in particular if pools are small.

Patterns of carbon isotopic signatures, levels of $\mathrm{H}_{2}$ concentrations of $\sim 10 \mathrm{nmol} \mathrm{L}^{-1}$ sufficient to maintain hydrogenotrophic methanogenesis (Heimann et al., 2010) and low DIC : $\mathrm{CH}_{4}$ ratios suggested methanogenic conditions over the whole profile (Figs. 4c, 5c). Methanogenesis was especially indicated by a slight peak of $\mathrm{CH}_{4}$ concentrations associated with lower DIC : $\mathrm{CH}_{4}$ ratios and elevated $\mathrm{H}_{2}$ ratios around $0.3 \mathrm{~m}$ in depth. However, even high activity of fermentation processes as indicated by peaking $\mathrm{H}_{2}$ levels from 1 to $2 \mathrm{~m}$ in depth did not translate to changes in fractionation factor (Figs. 4f, 5a) but suggest that $\mathrm{CH}_{4}$ was produced only very locally if at all. Low substrate supply from highly decomposed organic matter and thus unfavourable thermodynamic conditions seemed to limit $\mathrm{CH}_{4}$ production as suggested by very negative $\delta^{13} \mathrm{C}-\mathrm{CH}_{4}$ signatures (Fig. 4d) accompanied by peaking $\alpha_{\mathrm{c}}$ values in the upper profile (Fig. 4f) (Hornibrook et al., 1997; Knorr et al., 2008b). Instead, methanogenesis might have been outcompeted by other electron-accepting processes, such as sulfate reduction (Fig. 5c). If produced at all, $\mathrm{CH}_{4}$ was rapidly consumed around $0.3 \mathrm{~m}$ in depth by methanotrophic bacteria inhabiting submerged Sphagnum mosses that provided recalcitrant organic matter on pool bottoms (Kleinebecker et al., 2007; Kip et al., 2012; Knoblauch et al., 2015) or were associated with cyanobacteria (Arsenault et al., 2018; González Garraza et al., 2018). Within the open water of pools, which was well mixed by strong winds, $\mathrm{CH}_{4}$ production and excess of $\mathrm{H}_{2}$ were diminished due to electron acceptor availability for consumption (e.g. $\mathrm{O}_{2}$, sulfate). Thus, the pools at our study site belonged to examples of low-emission pools as described in Knoblauch et al. (2015).

\subsection{Sphagnum and Donatia lawns - low- to moderate-emission scenario}

$\mathrm{CH}_{4}$ emissions from Sphagnum and Donatia lawns were most variable among microforms ranging from near zero to local emission hotspots. Sphagnum lawns showed significantly higher $\mathrm{CH}_{4}$ emissions of $1.52 \pm 1.10 \mathrm{mmol} \mathrm{m}^{-2} \mathrm{~d}^{-1}$ than all other microforms (Fig. 3). Substantially higher fluxes from Sphagnum lawns at our study site have been previously described by Fritz et al. (2011) and emissions reported here were on the same order of magnitude as determined for Sphagnum lawns in south Patagonian bogs dominated by Sphagnum mosses (Broder et al., 2015; Lehmann et al., 2016). The highest emissions obtained in the present study from Sphagnum and Donatia lawns were at intermediate levels compared to northern bogs (Blodau, 2002; Laine et al., 2007; Limpens et al., 2008).
We present the first $\mathrm{CH}_{4}$ emission data obtained from $\mathrm{Do}$ natia lawns. Contrary to our expectations, Donatia lawns emitted $0.66 \pm 0.96 \mathrm{mmol} \mathrm{CH}_{4} \mathrm{~m}^{-2} \mathrm{~d}^{-1}$ and thus had the second highest $\mathrm{CH}_{4}$ emissions of our study. One lawn even exceeded emissions of the strongest Sphagnum lawn source (Fig. 3c, Table 2) on all measurement occasions. As these comparatively high emissions could be reproduced well, we conclude that an artefact can be excluded. Therefore, our first hypothesis, that cushion plants emit negligible amounts of $\mathrm{CH}_{4}$, could retrospectively only be partly confirmed, as it depends on the specific cushion-forming plant species. We conclude that the presence of cushion plants as a proxy for negligible $\mathrm{CH}_{4}$ emissions from cushion bogs needs to be carefully interpreted.

The spatial distribution of vascular plant root characteristics and its oxidative effects apparently controlled $\mathrm{CH}_{4}$ dynamics at the study site as suggested by the pronounced spatial variability in emissions associated with our preliminary observations of microform features (Table 2). D. fascicularis established a deep and aerenchymous, but with $<0.05 \mathrm{~g} \mathrm{DW} \mathrm{L}$ of peat ${ }^{-1}$, a substantially less dense rooting system compared to $A$. pumila with $>4 \mathrm{~g} \mathrm{DW} \mathrm{L} \mathrm{of} \mathrm{peat}^{-1}$ at around $0.5 \mathrm{~m}$ in depth (Fritz et al., 2011). The lower root density of $D$. fascicularis was probably below a specific threshold at which $\mathrm{O}_{2}$ release did not suppress emissions any more. Instead, the roots might have accelerated $\mathrm{CH}_{4}$ production through the presence of labile organic matter while facilitating emissions (e.g. Joabsson et al., 1999; Blodau, 2002; Colmer, 2003; Whalen, 2005; Agethen et al., 2018). As root $\mathrm{O}_{2}$ release promotes nutrient mobilization (Colmer, 2003), this assumption of little if any $\mathrm{O}_{2}$ release by $D$. fascicularis is in line with Schmidt et al. (2010), who found nutrient concentrations in D. fascicularis to be almost as low as in $S$. magellanicum while A. pumila contained significantly higher amounts of nutrients.

Sphagnum and Donatia lawns that showed substantial $\mathrm{CH}_{4}$ emissions were beyond the sphere of influence by A. pumila roots. Although not measured here, pore water $\mathrm{CH}_{4}$ concentrations below Sphagnum and Donatia lawns with remarkably higher emissions probably increased steeply below the water table (Fig. 6), like common depth profiles in northern (e.g. Beer and Blodau, 2007; Limpens et al., 2008; Corbett et al., 2013) or southern bogs (Broder et al., 2015). This explanation implies that the pore water below those lawns was not well connected to pore water influenced by A. pumila roots. A spatial variability in peat physical properties on the ecosystem scale was suggested by water table records (Fig. 2), demonstrating that one site responded faster than the other to, for instance, precipitation events.

We speculate that the biogeochemistry below Sphagnum and Donatia lawns with near-zero emissions was, similar to pools, influenced by root activity of nearby A. pumila (as visualized in Fig. 6). This assumption was supported by previous research at our study site. Fritz et al. (2011) showed that below Sphagnum lawns pore water $\mathrm{CH}_{4}$ concentrations can 
be substantially lowered throughout rhizosphere-influenced peat layers. Further research should be undertaken to investigate why $\mathrm{CH}_{4}$ emissions from Sphagnum and Donatia lawns appear to be highly variable in order to understand $\mathrm{CH}_{4} \mathrm{dy}$ namics in under-researched cushion bogs.

\subsection{Implications for ecosystem $\mathrm{CH}_{4}$ emissions from Patagonian cushion bogs}

The highest summer emissions in the present study were considerably lower compared to maximum austral summer fluxes of $\sim 150 \mathrm{mg} \mathrm{CH}_{4} \mathrm{~m}^{-2} \mathrm{~d}^{-1}\left(9.4 \mathrm{mmol} \mathrm{m}^{-2} \mathrm{~d}^{-1}\right)$ determined for a New Zealand bog dominated by the vascular evergreen wire rush, Empodisma robustum (Goodrich et al., 2015). The authors explained such high $\mathrm{CH}_{4}$ emissions by comparatively wet conditions and a high density of aerenchymous vegetation providing a gas conduit for $\mathrm{CH}_{4}$ transport in their study site. Compared to $\mathrm{CH}_{4}$ emissions of northern bogs ranging from 3 to $53 \mathrm{mg} \mathrm{m}^{-2} \mathrm{~d}^{-1}$ at intermediate levels in wet bogs to up to $80 \mathrm{mg} \mathrm{m}^{-2} \mathrm{~d}^{-1}$ (Blodau, 2002; Laine et al., 2007; Limpens et al., 2008; 0.2 to 2.2 and up to $5 \mathrm{mmol} \mathrm{m}^{-2} \mathrm{~d}^{-1}$ ), the highest summer emissions in the present study represent a pronounced $\mathrm{CH}_{4}$ source. Nevertheless, overall ecosystem $\mathrm{CH}_{4}$ emissions would probably be among the lowest described for pristine bog ecosystems worldwide when taking into account the high proportion of the surface area where Astelia lawns prevailed.

While Donatia lawns covered only small parts of our study site, we observed other parts of the complex bog system in the whole study area to be widely dominated by $D$. fascicularis instead of A. pumila, which is in line with previous studies (Heusser, 1995; Grootjans et al., 2014) that described the cushion bogs in the Moat landscape to be covered by both, A. pumila and D. fascicularis. Thus, amounts of emitted $\mathrm{CH}_{4}$ could also be significant on the ecosystem scale once $D$. fascicularis dominates. For instance, a predominance of $D$. fascicularis is typical for later vegetation succession stages in cushion bogs of Tierra del Fuego (Heusser, 1995) or Chile (Ruthsatz and Villagran, 1991; Kleinebecker et al., 2007).

\section{Conclusion}

We conclude from our study that the spatial distribution of cushion-forming A. pumila root density and activity and associated $\mathrm{O}_{2}$ supply strongly controlled $\mathrm{CH}_{4}$ production and consumption in a pristine Patagonian cushion bog. Thereby, $\mathrm{CH}_{4}$ emissions were reduced to near-zero levels and largely decoupled from environmental controls. The high root density even regulated $\mathrm{CH}_{4}$ dynamics below adjacent microforms with less or non-rooted peat such as pools, Sphagnum lawns or lawns dominated by cushion-forming D. fascicularis by maintaining lateral concentration gradients in upper peat layers. Nevertheless, when root density dropped below a certain threshold, $\mathrm{CH}_{4}$ production might have been acceler- ated by the presence of labile root organic matter or exudates accompanied by $\mathrm{O}_{2}$ consumption along with facilitated $\mathrm{CH}_{4}$ transport by aerenchymatic roots of $D$. fascicularis. Under such circumstances, $\mathrm{CH}_{4}$ emissions increased to intermediate levels compared to northern bogs. Therefore, the presence of cushion plants as a proxy for negligible $\mathrm{CH}_{4}$ emissions from cushion bogs should be interpreted carefully. As cushion bogs can be found in many (mostly southern) parts of the world and only very limited knowledge about $\mathrm{CH}_{4}$ dynamics from these systems exists, future research should take into account a possibly high spatial variability in $\mathrm{CH}_{4}$ emission from bogs dominated by cushion plants. We demonstrated an extreme scenario for how a spatial distribution of root density in the peat can lead to a pronounced pattern of $\mathrm{CH}_{4}$ emissions. Yet, the underlying ratio between root characteristics and $\mathrm{O}_{2}$ supply determining this emission pattern should be applicable to other densely rooted peatlands in general. Further research should be undertaken to prove relationships that have been developed here on a conceptual level in order to extend our knowledge on $\mathrm{CH}_{4}$ dynamics in under-researched cushion bogs.

Data availability. The data can be accessed by email request to the corresponding authors.

Supplement. The supplement related to this article is available online at: https://doi.org/10.5194/bg-16-541-2019-supplement.

Author contributions. CB, TK and WM designed the study. WM, $\mathrm{CB}$, TK and VAP conducted field work and sample analyses with the help of KHK. WM performed data analyses and prepared the paper with contributions from KHK, TK and VAP.

Competing interests. The authors declare that they have no conflict of interest.

Acknowledgements. This study was carried out within the research project CANDYbog, which was funded by the Deutsche Forschungsgemeinschaft (German Research Foundation, DFG; grant nos. KL2265/3-1 and BL 563/19-1). We highly appreciated the Centro Austral de Investigaciones Científicas (CADICCONICET) providing facilities that enabled our fieldwork in Ushuaia. The Prefectura Naval Argentina is acknowledged for offering facilities supporting our fieldwork. Lucas Varela of the La Posta Hostel family is appreciated for offering working space and logistics. We wish to acknowledge the laborious field assistance of Isabella Närdemann, Carla Bockermann, Claudia Frank, Bettina Breuer, Lina Birkner, Juliane Kohlstruck, Laura Jansen, David Holl, Lars Kutzbach, María Florencia Castagnani and María Noel Szudruk Pascual. All analyses of this study were carried out in the laboratory of the Institute of Landscape Ecology. The assistance of Ulrike Berning-Mader, Sebastian R. Schmidt, Ronya Wallis, 
Sabrina Knaack, Sina Berger, Simona Bonaiuti and Leandra Praetzel is greatly acknowledged. We thank Peter Sulmann for technical assistance. We are grateful for the valuable comments of the two anonymous referees. The support by Open Access Publication Fund of the University of Münster is acknowledged.

Edited by: Luo Yu

Reviewed by: two anonymous referees

\section{References}

Agethen, S., Sander, M., Waldemer, C., and Knorr, K.-H.: Plant rhizosphere oxidation reduces methane production and emission in rewetted peatlands, Soil Biol. Biochem., 125, 125-135, 2018.

Arsenault, J., Talbot, J., and Moore, T. R.: Environmental controls of $\mathrm{C}, \mathrm{N}$ and $\mathrm{P}$ biogeochemistry in peatland pools, Sci. Total Environ., 631-632, 714-722, 2018.

Aselmann, I. and Crutzen, P. J.: Global distribution of natural freshwater wetlands and rice paddies, their net primary productivity, seasonality and possible methane emissions, J. Atmos. Chem., 8, 307-358, 1989.

Baird, A. J., Milner, A. M., Blundell, A., Swindles, G. T., and Morris, P. J.: Microform-scale variations in peatland permeability and their ecohydrological implications, J. Ecol., 104, 531-544, 2016.

Beer, J. and Blodau, C.: Transport and thermodynamics constrain belowground carbon turnover in a northern peatland, Geochim. Cosmochim. Ac., 71, 2989-3002, 2007.

Beer, J., Lee, K., Whiticar, M., and Blodau, C.: Geochemical controls on anaerobic organic matter decomposition in a northern peatland, Limnol. Oceanogr., 53, 1393-1407, 2008.

Benavides, J. C., Vitt, D. H., and Wieder, R. K.: The influence of climate change on recent peat accumulation patterns of Distichia muscoides cushion bogs in the high-elevation tropical Andes of Colombia, J. Geophys. Res.-Biogeo., 118, 1627-1635, 2013.

Berg, P., Risgaard-Petersen, N., and Rysgaard, S.: Interpretation of measured concentration profiles in sediment pore water, Limnol. Oceanogr., 43, 1500-1510, 1998.

Berger, S., Praetzel, L. S. E., Goebel, M., Blodau, C., and Knorr, K.-H.: Differential response of carbon cycling to longterm nutrient input and altered hydrological conditions in a continental Canadian peatland, Biogeosciences, 15, 885-903, https://doi.org/10.5194/bg-15-885-2018, 2018.

Blodau, C.: Carbon cycling in peatlands - A review of processes and controls, Environ. Rev., 10, 111-134, 2002.

Blodau, C. and Moore, T. R.: Experimental response of peatland carbon dynamics to a water table fluctuation, Aquat. Sci., 65, 47-62, 2003.

Bonaiuti, S., Blodau, C., and Knorr, K.-H.: Transport, anoxia and end-product accumulation control carbon dioxide and methane production and release in peat soils, Biogeochemistry, 133, 219239, 2017.

Borromei, A. M., Ponce, J. F., Coronato, A., Candel, M. S., Olivera, D., and Okuda, M.: Reconstrucción de la vegetación posglacial y su relación con el ascenso relativo del nivel del mar en el extremo este del canal Beagle, Tierra del Fuego, Argentina, Andean Geol., 41, 362-379, 2014.
Boucher, F. C., Lavergne, S., Basile, M., Choler, P., and Aubert, S.: Evolution and biogeography of the cushion life form in angiosperms, Perspect. Plant Ecol., 20, 22-31, 2016.

Broder, T., Blodau, C., Biester, H., and Knorr, K. H.: Sea spray, trace elements, and decomposition patterns as possible constraints on the evolution of $\mathrm{CH}_{4}$ and $\mathrm{CO}_{2}$ concentrations and isotopic signatures in oceanic ombrotrophic bogs, Biogeochemistry, 122, 327-342, 2015.

Burger, M., Berger, S., Spangenberg, I., and Blodau, C.: Summer fluxes of methane and carbon dioxide from a pond and floating mat in a continental Canadian peatland, Biogeosciences, 13, 3777-3791, https://doi.org/10.5194/bg-13-3777-2016, 2016.

Chasar, L. S., Chanton, J. P., Glaser, P. H., and Siegel, D. I.: Methane concentration and stable isotope distribution as evidence of rhizospheric processes: Comparison of a fen and bog in the Glacial Lake Agassiz Peatland complex, Ann. Bot.-London, 86, 655663, 2000.

Colmer, T. D.: Long-distance transport of gases in plants: a perspective on internal aeration and radial oxygen loss from roots, Plant. Cell. Environ., 26, 17-36, 2003.

Conrad, R.: Quantification of methanogenic pathways using stable carbon isotopic signatures: a review and a proposal, Org. Geochem., 36, 739-752, 2005.

Coombes, L. and Ramsay, P. M.: Vegetation of a cushion mire at 3600 m on Volcán Chiles, Ecuador, in: The Ecology of Volcán Chiles. High altitude ecosystems on the Ecuador Colombia border, edited by: Ramsay, P. M., Pebble \& Shell Publications, Plymouth, UK, 47-54, 2001.

Corbett, J. E., Tfaily, M. M., Burdige, D. J., Cooper, W. T., Glaser, P. H., and Chanton, J. P.: Partitioning pathways of $\mathrm{CO}_{2}$ production in peatlands with stable carbon isotopes, Biogeochemistry, 114, 327-340, 2013.

Dullo, B. W., Grootjans, A. P., Roelofs, J. G. M., Senbeta, A. F., Fritz, C., and Lamers, L. P. M.: Radial oxygen loss by the cushion plant Eriocaulon schimperi prevents methane emissions from an East-African mountain mire, Plant Biol., 19, 736-741, 2017.

Eckhardt, T. and Kutzbach, L.: MATLAB code to calculate gas fluxes from chamber based methods. Institute of Soil Science, Hamburg, Germany, https://doi.org/10.1594/PANGAEA.857799, last access: 17 July 2016.

Estop-Aragonés, C., Knorr, K.-H., and Blodau, C.: Belowground in situ redox dynamics and methanogenesis recovery in a degraded fen during dry-wet cycles and flooding, Biogeosciences, 10, 421436, https://doi.org/10.5194/bg-10-421-2013, 2013.

Fechner-Levy, E. J. and Hemond, H. F.: Trapped methane volume and potential effects on methane ebullition in a northern peatland, Limnol. Oceanogr., 41, 1375-1383, 1996.

Fonkén, M. S. M.: An introduction to the bofedales of the Peruvian High Andes, Mires Peat, 15, 1-13. 2014.

Fritz, C.: Limits of Sphagnum bog growth in the New World: Biochemistry and ecohydrology of peatlands in South America and New Zealand, PhD thesis, Radboud University of Nijmegen/University of Groningen, the Netherlands, 193 pp., 2012

Fritz, C., Pancotto, V. A., Elzenga, J. T. M., Visser, E. J. W., Grootjans, A. P., Pol, A., Iturraspe, R., Roelofs, J. G. M., and Smolders, A. J. P.: Zero methane emission bogs: extreme rhizosphere oxygenation by cushion plants in Patagonia, New Phytol., 190, 398-408, 2011. 
Gibson, N. and Kirkpatrick, J. B.: A Comparison of the Cushion Plant-Communities of New-Zealand and Tasmania, New. Zeal. J. Bot., 23, 549-566, 1985.

González Garraza, G., Pancotto, V. A., Mansilla, R., and Escobar, J.: Importancia de la humedad en la caracterización de las comunidades microalgales en turberas compactas de Tierra del Fuego, in: Resúmenes de la Reunión Argentina de Ecología, XXVIII Reunión Argentina de Ecología, Mar del Plata, Argentina, 29 October-2 November 2018, p. 353, 2018.

Goodrich, J. P., Campbell, D. I., Roulet, N. T., Clearwater, M. J., and Schipper, L. A.: Overriding control of methane flux temporal variability by water table dynamics in a Southern Hemisphere, raised bog, J. Geophys. Res.-Biogeo., 120, 819-831, 2015.

Grootjans, J., Iturraspe, R., Fritz, C., Moen, A., and Joosten, H.: Mires and mire types of Peninsula Mitre, Tierra del Fuego, Argentina, Mires Peat, 14, 1-20, 2014.

Hamilton, J. D., Kelly, C. A., Rudd, J. W. M., Hesslein, R. H., and Roulet, N. T.: Flux to the atmosphere of $\mathrm{CH}_{4}$ and $\mathrm{CO}_{2}$ from wetland ponds on the Hudson Bay lowlands (HBLs), J. Geophys. Res.-Atmos., 99, 1495-1510, 1994.

Heimann, A., Jakobsen, R., and Blodau, C.: Energetic Constraints on H2-Dependent Terminal Electron Accepting Processes in Anoxic Environments: A Review of Observations and Model Approaches, Environ. Sci. Technol., 44, 24-33, 2010.

Heusser, C. J.: Paleoecology of a Donatia-Astelia Cushion Bog, Magellanic Moorland-Sub-Antarctic Evergreen Forest Transition, Southern Tierra-Del-Fuego, Argentina, Rev. Palaeobot. Palyno., 89, 429-440, 1995.

Hope, G. S.: Peat in the mountains of New Guinea, Mires Peat, 15, 1-21, 2014.

Hornibrook, E. R. C., Longstaffe, F. J., and Fyfe, W. S.: Spatial distribution of microbial methane production pathways in temperate zone wetland soils: Stable carbon and hydrogen isotope evidence, Geochim. Cosmochim. Ac., 61, 745-753, 1997.

Hornibrook, E. R. C., Longstaffe, F. J., and Fyfe, W. S.: Evolution of stable carbon isotope compositions for methane and carbon dioxide in freshwater wetlands and other anaerobic environments, Geochim. Cosmochim. Ac., 64, 1013-1027, 2000.

IPCC: Anthropogenic and Natural Radiative Forcing, in: Climate Change 2013 - The Physical Science Basis: Working Group I Contribution to the Fifth Assessment Report of the Intergovernmental Panel on Climate Change, edited by: Change, I. P. o. C., Cambridge University Press, Cambridge, UK, 659-740, 2014.

Iturraspe, R.: Spatial analysis and description of eastern peatlands of Tierra del Fuego, Argentina, in: Mires from pole to pole, edited by: Lindholm, T., and Heikkilä, R., Finnish Environment Institute (SYKE), Helsinki, Finland, 2012.

Jackowicz-Korczyński, M., Christensen, T. R., Bäckstrand, K., Crill, P., Friborg, T., Mastepanov, M., and Ström, L.: Annual cycle of methane emission from a subarctic peatland, J. Geophys. Res.-Biogeo., 115, https://doi.org/10.1029/2008JG000913, 2010.

Joabsson, A., Christensen, T. R., and Wallén, B.: Vascular plant controls on methane emissions from northern peatforming wetlands, Trends Ecol. Evol., 14, 385-388, 1999.

Kip, N., Fritz, C., Langelaan, E. S., Pan, Y., Bodrossy, L., Pancotto, V., Jetten, M. S. M., Smolders, A. J. P., and Op den Camp, H. J. M.: Methanotrophic activity and diversity in different Sphagnum magellanicum dominated habitats in the south- ernmost peat bogs of Patagonia, Biogeosciences, 9, 47-55, https://doi.org/10.5194/bg-9-47-2012, 2012.

Kleinebecker, T., Hölzel, N., and Vogel, A.: Gradients of continentality and moisture in South Patagonian ombrotrophic peatland vegetation, Folia Geobot., 42, 363-382, 2007.

Kleinebecker, T., Hölzel, N., and Vogel, A.: South Patagonian ombrotrophic bog vegetation reflects biogeochemical gradients at the landscape level, J. Veg. Sci., 19, 151-160, 2008.

Knoblauch, C., Spott, O., Evgrafova, S., Kutzbach, L., and Pfeiffer, E.-M.: Regulation of methane production, oxidation, and emission by vascular plants and bryophytes in ponds of the northeast Siberian polygonal tundra, J. Geophys. Res.-Biogeo., 120, 25252541, 2015.

Knorr, K. H., Oosterwoud, M. R., and Blodau, C.: Experimental drought alters rates of soil respiration and methanogenesis but not carbon exchange in soil of a temperate fen, Soil Biol. Biochem., 40, 1781-1791, 2008a.

Knorr, K.-H., Glaser, B., and Blodau, C.: Fluxes and ${ }^{13} \mathrm{C}$ isotopic composition of dissolved carbon and pathways of methanogenesis in a fen soil exposed to experimental drought, Biogeosciences, 5, 1457-1473, https://doi.org/10.5194/bg-5-14572008, 2008b.

Knorr, K.-H., Lischeid, G., and Blodau, C.: Dynamics of redox processes in a minerotrophic fen exposed to a water table manipulation, Geoderma, 153, 379-392, 2009.

Knorr, K.-H., Horn, M. A., and Borken, W.: Significant nonsymbiotic nitrogen fixation in Patagonian ombrotrophic bogs, Global Change Biol., 21, 2357-2365, 2015.

Kotsyurbenko, O. R., Glagolev, M. V., Nozhevnikova, A. N., and Conrad, R.: Competition between homoacetogenic bacteria and methanogenic archaea for hydrogen at low temperature, Fems Microbiol. Ecol., 38, 153-159, 2001.

Kutzbach, L., Schneider, J., Sachs, T., Giebels, M., Nykänen, H., Shurpali, N. J., Martikainen, P. J., Alm, J., and Wilmking, M.: $\mathrm{CO}_{2}$ flux determination by closed-chamber methods can be seriously biased by inappropriate application of linear regression, Biogeosciences, 4, 1005-1025, https://doi.org/10.5194/bg4-1005-2007, 2007.

Laine, A., Wilson, D., Kiely, G., and Byrne, K. A.: Methane flux dynamics in an Irish lowland blanket bog, Plant Soil, 299, 181193, 2007.

Lehmann, J., Münchberger, W., Knoth, C., Blodau, C., Nieberding, F., Prinz, T., Pancotto, V., and Kleinebecker, T.: High-Resolution Classification of South Patagonian Peat Bog Microforms Reveals Potential Gaps in Up-Scaled $\mathrm{CH}_{4}$ Fluxes by use of Unmanned Aerial System (UAS) and CIR Imagery, Remote Sens.-Basel, 8, 173, 2016.

Limpens, J., Berendse, F., Blodau, C., Canadell, J. G., Freeman, C., Holden, J., Roulet, N., Rydin, H., and Schaepman-Strub, G.: Peatlands and the carbon cycle: from local processes to global implications - a synthesis, Biogeosciences, 5, 1475-1491, https://doi.org/10.5194/bg-5-1475-2008, 2008.

Mainiero, R. and Kazda, M.: Effects of Carex rostrata on soil oxygen in relation to soil moisture, Plant Soil, 270, 311-320, 2005.

Mikaloff Fletcher, S. E., Tans, P. P., Bruhwiler, L. M., Miller, J. B., and Heimann, M.: $\mathrm{CH} 4$ sources estimated from atmospheric observations of $\mathrm{CH}_{4}$ and its ${ }^{13} \mathrm{C} /{ }^{12} \mathrm{C}$ isotopic ratios: 1 . Inverse modeling of source processes, Global Biogeochem. Cy., 18,2004 
Paredes, N. I., Consolo, V. F., Pancotto, V. A., Fritz, C., Barrera, M. D., Arambarri, A. M., and Salerno, G. L.: Microfungal composition in an Astelia-Donatia cushion peatland in Tierra del Fuego, Argentina, Darwinia, 2, 112-124, 2014.

Pelletier, L., Strachan, I. B., Garneau, M., and Roulet, N. T.: Carbon release from boreal peatland open water pools: Implication for the contemporary C exchange, J. Geophys. Res.-Biogeo., 119, 207-222, 2014.

Popp, T. J., Chanton, J. P., Whiting, G. J., and Grant, N.: Methane stable isotope distribution at a Carex dominated fen in north central Alberta, Global Biogeochem. Cy., 13, 1063-1077, 1999.

Rinne, J., Riutta, T., Pihlatie, M., Aurela, M., Haapanala, S., Tuovinen, J.-P., Tuittila, E.-S., and Vesala, T.: Annual cycle of methane emission from a boreal fen measured by the eddy covariance technique, Tellus B, 59, 449-457, 2007.

Ruthsatz, B. and Villagran, C.: Vegetation Pattern and Soil Nutrients of a Magellanic Moorland on the Cordillera-De-Piuchue, Chiloe Island, Chile, Rev. Chil. Hist. Nat., 64, 461-478, 1991.

Sander, R.: Compilation of Henry's Law constants for inorganic and organic species of potential importance in environmental chemistry, Max Planck Institute of Chemistry, Mainz, Germany, available at: http://satellite.mpic.de/henry_data/henry-3.0. pdf (last access: 1 June 2017), 1999

Schmidt, S. R., Kleinebecker, T., Vogel, A., and Holzel, N.: Interspecific and geographical differences of plant tissue nutrient concentrations along an environmental gradient in Southern Patagonia, Chile, Aquat. Bot., 92, 149-156, 2010.
Steinmann, P., Eilrich, B., Leuenberger, M., and Burns, S. J.: Stable carbon isotope composition and concentrations of $\mathrm{CO}_{2}$ and $\mathrm{CH}_{4}$ in the deep catotelm of a peat bog, Geochim. Cosmochim. Ac., 72, 6015-6026, 2008.

Stumm, W. and Morgan, J. J.: Aquatic chemistry. Chemical Equilibria and Rates in Natural Waters, 3rd ed., Wiley, Hoboken, NJ, USA, 1996.

von Mering, S.: Tetroncium and its only species, T. magellanicum (Juncaginaceae): distribution, ecology and lectotypification, Willdenowia, 43, 13-24, 2013.

Whalen, S. C.: Biogeochemistry of Methane Exchange between Natural Wetlands and the Atmosphere, Environ. Eng. Sci., 22, 73-94, 2005.

Whiticar, M. J., Faber, E., and Schoell, M.: Biogenic methane formation in marine and freshwater environments: $\mathrm{CO}_{2}$ reduction vs. acetate fermentation - Isotope evidence, Geochim. Cosmochim. Ac., 50, 693-709, 1986.

Yu, Z. C.: Northern peatland carbon stocks and dynamics: a review, Biogeosciences, 9, 4071-4085, https://doi.org/10.5194/bg9-4071-2012, 2012. 